\title{
The Trash-Tracker: A Macroplastic Transport and Fate Model at River Basin Scale
}

\author{
Y.A.M. Mellink ${ }^{1,2}$, T.H.M. van Emmerik ${ }^{1}$, M. Kooi ${ }^{3}$, C. Laufkötter ${ }^{4,5}$, and H. Niemann6,2,7 \\ ${ }^{1}$ Hydrology and Quantitative Water Management Group, Wageningen University, Wageningen, the Netherlands \\ ${ }^{2}$ Department of Earth Sciences, Faculty of Geosciences, Utrecht University, Utrecht, the Netherlands \\ ${ }^{3}$ Aquatic Ecology and Water Quality Group, Wageningen University, Wageningen, the Netherlands \\ ${ }^{4}$ Climate and Environmental Physics, Physics Institute, University of Bern, Bern, Switzerland \\ ${ }^{5}$ Oeschger Centre for Climate Change Research, University of Bern, Bern, Switzerland \\ ${ }^{6}$ Department of Marine Microbiology and Biogeochemistry, NIOZ Royal Netherlands Institute for Sea Research, 't Horntje, the \\ Netherlands \\ ${ }^{7}$ CAGE - Centre for Arctic Gas Hydrate, Environment and Climate, Department of Geosciences, UiT The Arctic University of \\ Norway, Tromsø, Norway
}

Email addresses:

$\begin{array}{ll}\text { Y.A.M. Mellink } & \underline{\text { mellinkyvette@gmail.com }} \\ \text { T.H,M. van Emmerik } & \underline{\text { tim.vanemmerik@wur.nl }} \\ \text { M. Kooi } & \underline{\text { merel.kooi@wur.nl }} \\ \text { C. Laufkötter } & \underline{\text { c.laufkoetter@googlemail.com }} \\ \text { H. Niemann } & \underline{\text { helge.niemann@nioz.nl }}\end{array}$

This manuscript is a pre-print submitted to EarthArXiv and has been submitted for publication in Microplastics and Nanoplastics. Subsequent versions may have slightly different content. The DOI of the peer-reviewed publication will be provided if accept. Please contact the authors if you have any questions or comments on this manuscript. 


\title{
1 The Trash-Tracker: A Macroplastic Transport and Fate \\ 2 Model at River Basin Scale
}

3

\author{
Y.A.M. Mellink ${ }^{1,2}$, T.H.M. van Emmerik ${ }^{1}$, M. Kooi ${ }^{3}$, C. Laufkötter ${ }^{4,5}$, and H. Niemann $n^{6,2,7}$
}

${ }^{1}$ Hydrology and Quantitative Water Management Group, Wageningen University, Wageningen, the Netherlands

${ }^{2}$ Department of Earth Sciences, Faculty of Geosciences, Utrecht University, Utrecht, the Netherlands

${ }^{3}$ Aquatic Ecology and Water Quality Group, Wageningen University, Wageningen, the Netherlands

${ }^{4}$ Climate and Environmental Physics, Physics Institute, University of Bern, Bern, Switzerland

${ }^{5}$ Oeschger Centre for Climate Change Research, University of Bern, Bern, Switzerland

${ }^{6}$ Department of Marine Microbiology and Biogeochemistry, NIOZ Royal Netherlands Institute for Sea Research, 't Horntje, the Netherlands

${ }^{7}$ CAGE - Centre for Arctic Gas Hydrate, Environment and Climate, Department of Geosciences, UiT The Arctic University of Norway, Tromsø, Norway

Corresponding author: Y.A.M. Mellink (mellinkyvette@gmail.com)

\section{Keywords}

Macroplastics, fate modelling, plastic mobilisation thresholds, spatiotemporal macroplastics distribution, plastic transport routes, terrestrial garbage patches

\section{Abstract}

Land-based plastic waste is assumed to be the major source for freshwater and marine plastic pollution. Yet, the transport pathways over land, in rivers and into the oceans remain highly uncertain. Here, we introduce a new modelling concept to predict plastic transport pathways on land: the Trash-Tracker, a numerical model that simulates the spatiotemporal distribution of macroplastic waste at the river basin scale. The plastic transporting agents are wind and surface runoff, while plastic transport is resisted by the friction of the terrain. The terrain resistance, a function of the terrain slope and type of land use, is translated to thresholds that define the critical wind and surface runoff conditions required to mobilise and transport macroplastic waste. When the wind and/or surface runoff conditions exceed their respective thresholds, the model simulates the transport of plastics, resulting in plastic accumulation hotspots maps and high probability transport route maps on the scale of river basins. The Trash-Tracker contributes to a better mechanistic understanding of plastic transport through terrestrial and freshwater systems, and upon future calibration and validation, can serve as a practical tool for stakeholders to optimise plastic waste prevention, mitigation, and reduction strategies. 


\section{Introduction}

Plastic pollution causes harm to wildlife (e.g. ingestion or entanglement [40]) and has negative impacts on human health (e.g. consumption of contaminated seafood $[32,38])$, on economic activities (e.g. damage to vessels or tourists repulsion), and on human livelihood (e.g. human health issues [54] and increased risks of local flooding due to clogged drains [49]). High production rates and extensive usage of plastics have caused the generation of plastic waste to exceed the capacity of the (local) waste management systems, allowing large amounts of mismanaged plastic waste (MPW) to enter the natural environment [12]. MPW is transported across terrestrial and freshwater ecosystems by aeolian and aquatic processes $[3,23,27,36,46]$ and is assumed to be the main source of marine plastic pollution $[5,21,55]$. Studies on the fraction of the MPW that is emitted into the ocean suggest that the majority of the produced land-based plastic waste is retained in terrestrial and freshwater systems [44, 46]. A recent modelling study by Meijer et al. [29] generated river basin scale plastic transport probability maps and estimated that less than $2 \%$ of the annually produced MPW within river basins is emitted to the oceans. Although this study offered great insights into the probability and driving mechanisms of plastic transport through river basins, the exact transport routes and accumulation hotspots of the remaining $98 \%$ of the produced MPW remain unresolved.

Currently, no plastic particle tracking model is available to resolve the (potential) trajectories of MPW within river basins, whereas such models have already been successfully developed for the marine environment $[8,16,22,28$, 52]. We developed the Trash-Tracker, a macroplastic particle tracking model concept for terrestrial and freshwater environments. The model concept is based on the assumption that macroplastic waste is mobilised and transported when the driving forces, wind and surface runoff, overcome the terrain friction caused by the (combination of the) type of land use and slope. The Trash-Tracker simulates the pathways of macroplastics and generates high resolution maps of the spatiotemporal distribution of macroplastics within river basins.

The Trash-Tracker contributes to a better fundamental understanding of plastic transport in terrestrial and freshwater systems, since it identifies the major transport routes and accumulation hotspots of plastics in river basins. It serves as a useful tool for developing and improving (inter)national river plastic monitoring, collection and mitigation strategies.

\section{Methods}

The model is written in Python 3.8.3 in the Jupyter Notebook (Version 6.0.3) environment, a package from Anaconda Navigator [1]. The code of the Trash-Tracker (v1.0.2) and the user's manual are available at 
http://doi.org/10.5281/zenodo.4546247. Below, we discuss the modelling concept and demonstrate its application using a fictional case study using real-world forcing data.

\subsection{Model Concept}

The model concept is based on a principal criterion in the field of sedimentology, which states that sediment motion is initiated when driving forces overcome resistive forces [39]. We presumed that the motion of macroplastics over land is a function of driving and resistive forces as well and that thresholds mark the conditions required for incipient motion (Fig. 1). The two driving forces in the model are wind $(W)$ and surface runoff (SR) (the same driving forces were used by Meijer et al. [29]) and the resisting force, i.e. the terrain friction, is a result of the combination of land use and terrain slope, which is translated to a wind $\left(W_{\text {thres }}\right)$ and a surface runoff threshold $\left(S R_{\text {thres }}\right)$. For each geographic location in the river basin, the wind speed $(W)$ and surface runoff flux $(S R)$ are compared with their respective thresholds. This comparison has four possible outcomes:

$$
\left\{\begin{array}{l}
W<W_{\text {thres }} \wedge S R<S R_{\text {thres }} \\
W \geq W_{\text {thres }} \wedge S R<S R_{\text {thres }} \\
W<W_{\text {thres }} \wedge S R \geq S R_{\text {thres }} \\
W>W_{\text {thres }} \wedge S R \geq S R_{\text {thres }}
\end{array}\right.
$$

In case none of the thresholds are surpassed (eq. 1), the macroplastics will not be mobilised and no transport occurs. If only the wind threshold is surpassed (eq. 2), the macroplastics will move in the direction of the wind at that geographic location. In case only the surface runoff threshold is surpassed (eq. 3), the macroplastics will move in the direction of the surface runoff, which is equal to the direction of the steepest downhill terrain slope at that geographic location. Finally, if both thresholds are surpassed (eq. 4), the model randomly picks either the wind or the surface runoff direction at that geographic location along which the macroplastics will move.

For each modelled time step the comparison of the wind and surface runoff with their respective thresholds results in transport vectors along which the macroplastics are transported. The start macroplastic distribution of a time step ('Start' in Fig. 2) consists of the mismanaged plastic waste generated at that time step ('MPW input' in Fig. 2) plus the end macroplastic distribution of the previous time step ('End' in Fig. 2). It is assumed that the mismanaged macroplastic waste generated during a single time step is exposed to the weather conditions of that same time step and is immediately available for transport. 


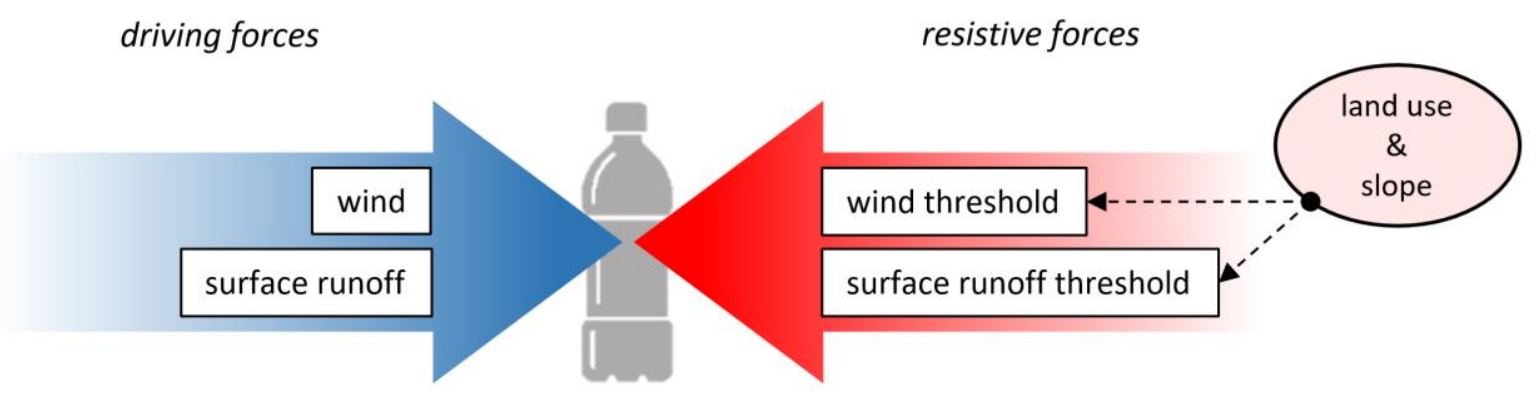

Fig. 1. Schematic representation of the main model concept of the Trash-Tracker. Plastics are mobilized once the driving forces exceed the resistive forces.

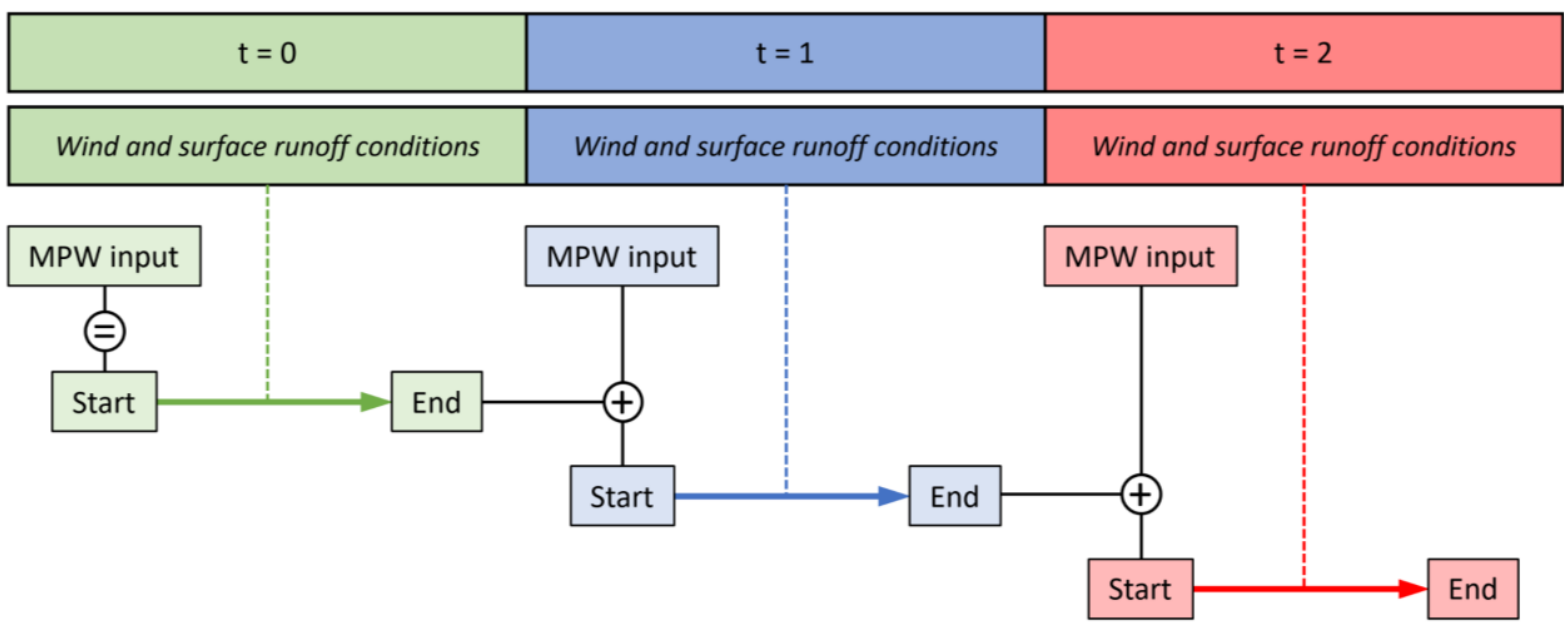

Fig. 2. Schematic representation of the model framework in which the start and end mismanaged plastic waste (MPW) distributions for each time step are computed. The start MPW distribution of a time step is the sum of the MPW input for that time step and the end MPW distribution of the previous time step. Except for $t=0$, where the start MPW distribution equals the MWP input for $t=0$.

\subsection{Model Framework}

The model framework is shown in Fig. 3. The surface runoff flux $(S R)$ can either be a direct input, or can be computed from a rainfall input data set. The surface runoff $\left(S R_{\text {thres }}\right)$ and wind speed $\left(W_{\text {thres }}\right)$ thresholds are computed from the topography and land use input (see section 2.5). The mobilisation map shows which thresholds are surpassed where based on the outcomes of the comparisons between the surface runoff fluxes $(S R)$ and wind speeds $(W)$ with their respective thresholds (eq. 1-4). The mobilisation map in combination with the surface runoff and wind directions allows the Trash-Tracker to generate a potential plastics routing map. The generation of mismanaged plastic waste is calculated from the population density and when combined with the mobilisation map, the surface runoff directions map and the wind direction map(s), a spatiotemporal macroplastic distribution map can be computed for each time step. 


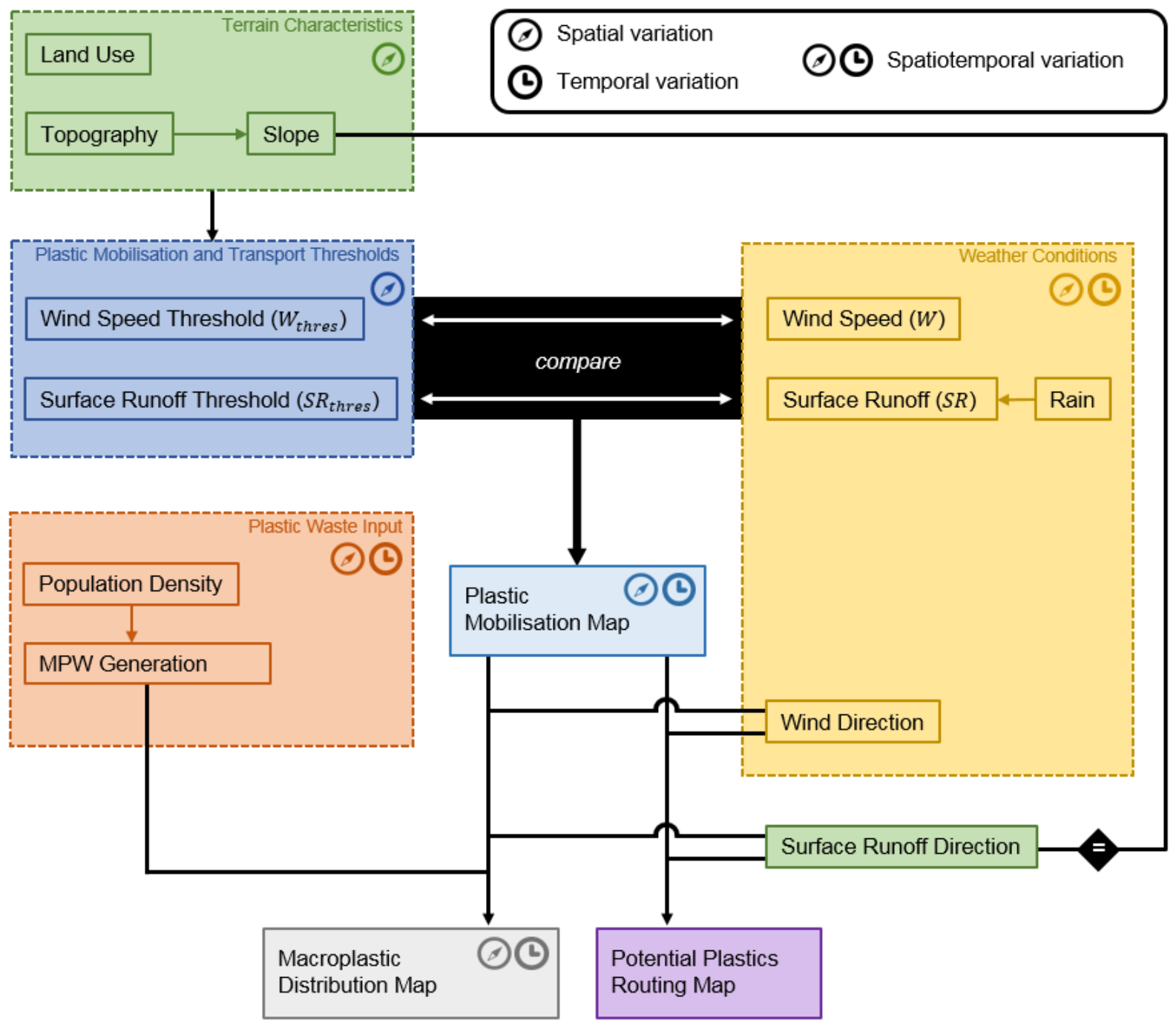

Fig. 3. Model framework of the Trash-Tracker.

\subsection{Model Resolutions}

The model is built on a rectangular [longitude, latitude] grid, with equally sized grid cells. Data on terrain characteristics are assigned to each grid cell and assumed to be representative for entire piece of land covered by that grid cell. The model can run on any spatial or temporal resolution depending on the required degree of detail and resolution of input data. However, we recommend to use a spatial resolution of $3 \times 3$ arc seconds ( 1 arc second $\sim 30 \mathrm{~m}$ ) as most geospatial data (e.g. elevation, land use, wind, rain, etc.) are available on such a grid. For the temporal resolution we recommend 1 day as the transporting agents, i.e. wind and surface runoff (rain), have daily variations.

\subsection{Modelled Directions of Motion}

All motions in the model occur in the two-dimensional horizontal plane. Analogous to the approach of Jenson and Domingue [17], the modelled components, e.g. air, water and plastics, can only move from one model grid cell 
to a neighbouring grid cell. As the model uses a rectangular grid, the directions of motion are restricted to eight: north, northeast, east, southeast, south, southwest, west and northwest.

\subsection{Modelled Plastic Mobilisation and Transport}

The model assumes that the mobilisation and transport thresholds, which mark the point where the driving forces overcome the resistive forces, solely depend on (the combination of) land use and terrain slope. The wind speed and surface runoff thresholds included in the model can be found in Supplementary Tab. SI1. The plastic mobilisation and transport thresholds were developed assuming that they increase with increasing terrain resistance.

\section{Wind driven transport}

The wind speed thresholds can be calculated as a function of only the type of land use - Option 1 - or as a function of the type of land use and the (combination of) terrain slope and wind direction - Option 2.

Option 1: Starting point in defining the wind speed thresholds was the Beaufort wind scale, which defines that wind speeds between 5.5 and $7.9 \mathrm{~m} / \mathrm{s}$ (BF4) "raise dust and loose paper" [30]. Combined with the assumption that flat bare land with no (natural or human-made) obstacles (e.g. vegetation or buildings) exerts the lowest resistive force to macroplastic transport, flat bare land was assigned a wind speed threshold of $6.6 \mathrm{~m} / \mathrm{s}$ (the average of 5.5 and $7.9 \mathrm{~m} / \mathrm{s}$ ). Subsequently, this wind speed threshold was extrapolated in order to obtain the thresholds for the four other land use types. The extrapolation factors for each type of land use were derived from plastic transport probability estimates from a group of experts obtained in a survey conducted by Meijer et al. [29] (see Supplementary Information SI3 and Fig. SI1). The wind speed threshold value for rivers was set to an extremely high value of $30 \mathrm{~m} / \mathrm{s}$, assuming that only violent storms and hurricanes (>BF11) can lift floating macroplastic waste from a river.

Option 2: For this calculation of the wind thresholds it was assumed that in case of winds blowing uphill/downhill, the ability of the wind to mobilise and transport macroplastics in the direction of the wind decreases (uphill winds) or increases (downhill winds), because it is counteracted (uphill winds) or assisted (downhill winds) by the force of gravity. For each radian of terrain slope angle, $4.2 \mathrm{~m} / \mathrm{s}$ was added or subtracted from the wind speed threshold values calculated using Option 1, i.e. the thresholds that hold for flat terrains. The value of $4.2 \mathrm{~m} / \mathrm{s}$ was determined by assuming that the wind speed threshold for (hypothetically) vertical bare lands equals $0.0 \mathrm{~m} / \mathrm{s}$ (free fall). This would imply a decrease of $6.6 \mathrm{~m} / \mathrm{s}$ of the wind speed threshold that corresponds to a terrain slope increase of $90^{\circ}$ $(1 / 2 \pi$ radians). Assuming a linear relation, this comes down to a decrease of $4.2 \mathrm{~m} / \mathrm{s}$ for each radian of terrain slope increase. An important implication of this approach is that the wind speed thresholds possibly do not only vary in space, but in time as well, because the wind directions can vary with time. For example, at time $t$, a certain wind speed at a specific location appears to be insufficient to mobilise and transport macroplastics, while at $t+1$, the same 
wind speed but in a different direction appears to be sufficient to surpass the wind speed threshold and consequently moves the macroplastics.

\section{Surface runoff driven transport}

The surface runoff thresholds define for each type of land use the critical flux of surface runoff that is presumed to be sufficient to mobilise and transport macroplastics. However, as far as we know, no study to date has examined such surface runoff thresholds. We made a first attempt and established the orders of magnitude for our surface runoff thresholds on the distribution of the data on global absolute runoff trends found in the Global Runoff Reconstruction (GRUN) model, an observational-based global reconstruction of (monthly) runoff developed by Ghiggi et al. [13]. We assumed that the higher the density of natural (e.g. vegetation) or anthropogenic obstacles (e.g. buildings), the more surface runoff is required to displace macroplastics. Therefore, the urban lands have the lowest surface runoff thresholds and forests the highest. Within one type of land use, the terrain slope determines the surface runoff threshold. It was assumed that the steeper the terrain slope, the higher the surface runoff flow velocity and the higher the capability of the surface runoff to mobilise and carry macroplastics. For grid cells that are only surrounded by other grid cells with a higher topography, the surface runoff threshold is set to a value of $1000 \mathrm{~mm} / \mathrm{d}$, because we assumed that only through the surface runoff flux caused by intense rainfall or floods is capable of carrying plastics uphill. As the terrain topography and land use are both assumed constant through time, the surface runoff thresholds only have a spatial variability.

Surface runoff is a land feature and does not apply to rivers, seas or lakes. However, the model requires a surface runoff threshold for each grid cell in the model domain, therefore the 'surface runoff threshold' for river grid cells was set to $0 \mathrm{~mm} / \mathrm{d}$. Once in the river, plastics will be transported by the river flow unhindered. Plastic retention in the river channel is not included in the model.

\section{Moving plastic trash clusters}

The model works with so called trash clusters, where a single trash cluster is comprised of all the mismanaged plastic waste (MPW) items that was generated in a single grid cell during a single time step. For simplicity, all plastic items behave the same, therefore when a threshold in a grid cell is surpassed, all items of the trash cluster present in that grid cell are transported. It is possible for trash clusters to merge. This can happen when two (or more) trash clusters are transported towards the same grid cell or when a new trash cluster is generated in a grid cell in which another trash cluster was already present. When trash clusters merge, their MPW masses are summed and hereafter will move as one (larger) trash cluster throughout the river basin. 


\subsection{Modelled Plastic Emissions}

The model allows for cross-boundary transport at the outer limits of the model domain, which means that plastic waste can get lost/be emitted from the modelled river basin. The model distinguishes between three types of emissions: (i) river emissions, (ii) coastal emissions and (iii) land-to-land emissions. The coastal and river emissions deliver plastics to the adjacent downstream aquatic basin (e.g. lake, sea, ocean etc.), whereas mismanaged plastic waste lost through land-to-land emissions end up on land in adjacent river basins (typically via aeolian transport).

\subsection{Model Input \& Input used for Model Application}

In this section, we describe the (type of) input data that the model requires and additionally provide the input data used for a model application. The model application presented in this study is meant to illustrate ('a proof of principle') the performances of the Trash-Tracker for a simple hypothetical river basin with a model domain of 30 by 30 arc seconds, a 3 by 3 arc seconds resolution (i.e. 100 grid cells), a modelled period of one year and a temporal resolution of 1 day. In the model application the wind speed thresholds are only a function of the type of land use (Option 1 - see section 2.5).

\section{Topography}

The topography input data defines for each grid cell the elevation above sea level in meters. For each grid cell the distance weight drop towards each of its neighbouring grid cells is calculated (topography data can be extracted from a database such as HydroSHEDS [25]). The model calculates the distance weighted drop in all eight directions and marks the smallest as the direction of the steepest downhill terrain slope. In case a grid cell is surrounded by grid cells with a higher topography, the smallest distance weighted drop marks the direction of the gentlest uphill slope. The topography map created for the model application is shown in Fig. 4a (the steepest downhill slopes direction and magnitude map can be found in Supplementary Fig. SI2).

\section{Land Use}

The land use input data defines for each grid cell the type of land use (land use data can be extracted from a database such as the ESA CII Land Cover time-series [9]). The Trash-Tracker distinguishes between water and five types of land use: urban land (artificial surfaces, e.g. cities), bare land (little or no vegetation), grass/shrub land (grass and/or shrub cover, e.g. pastures), agricultural land (edible plants vegetation, e.g. croplands) and forest (dense vegetation with trees, ranging from tropical rainforests to boreal forests). These land use categories were developed on the basis of the Land Cover Themes in the GLC2000 data set [4]. It is possible to add more types of land use. The land use map used for the model application (Fig. 4b) was manually made. The river drains towards an ocean south of the model domain and the bare land in the south represents a coastline. 
The wind input data provides for each time step for a given grid cell the daily averaged wind speed in meters per second and the average wind direction (the wind data can be extracted from a database such as the Global Wind Atlas [14]). The table to convert wind directions in degrees $\left(0^{\circ}-360^{\circ}\right)$ to the eight direction of motion used in the model can be found in Supplementary Tab. SI2. Wind speeds and directions used for the model application can be found in Supplementary Fig. SI3 and Tab. SI3, respectively. These wind speeds and directions have been generated for each time step based on frequency tables for wind speeds (see Supplementary Tab. SI4) [34] and wind directions (see Supplementary Tab. SI5) [35] computed from wind measurements at the De Bilt weather station from the Royal Netherlands Meteorological Institute (KNMI).

\section{Surface Runoff}

The surface runoff input data provides for each time step for a given grid cell the flux of surface runoff in millimetres per day (the surface runoff data can be extracted from a database such as GRUN [13]). Surface runoff can also be computed from rainfall data (extracted from regional/national weather stations) using a runoff coefficient. The runoff coefficient (= runoff / rainfall) is the fraction of the rainwater that does not infiltrate in the soil and consequently becomes surface runoff. The type of land cover (i.e. vegetation) plays a major role in this process. The surface runoff direction in each grid cell is equal to the direction of the steepest terrain slope of that grid cell (Supplementary Fig. SI2).

The rainfall values used in the model application can be found in Supplementary Fig. SI4. These values were generated on the basis of a frequency table for rainfall (see Supplementary Tab. SI6) [33] by the De Bilt weather station from the Royal Netherlands Meteorological Institute (KNMI). The runoff coefficients that were used to convert the rainfall values into surface runoff values can be found in Supplementary Tab. SI7 $[15,18]$.

The surface runoff flux and direction in river grid cells equal the river flow speed and direction, respectively. The Trash-Tracker assumes simple constant river flow dynamics, where for the model application the surface runoff flux for all river grid cells was set to $1000 \mathrm{~mm} / \mathrm{d}$ and the river flow directions were manually set to drain the water towards the south of the model domain (white arrows in land use map Fig. 4b).

\section{Mismanaged Plastic Waste Generation}

The mismanaged plastic waste (MPW) input data provides for each time step for each grid cell the mass of MPW generated in kilograms. If no MPW generation input data is available, it can be computed from the population density in combination with estimates on the (yearly) generation of solid municipal waste per capita, the fraction of waste that is mismanaged and the proportion of plastics in solid waste [24]. The population density map used for the model application show for each grid cell the number of inhabitants and can be found in Supplementary Fig. SI5. Forests were assigned an artificial population density of 0.1 people/grid cell $(\sim 12.3$ people/km²) in order to 
account for (occasional) littering associated to recreational activities. The yearly MPW generated in each grid cell was calculated using waste values reported for the Netherlands for the year 2015: $526 \mathrm{~kg}$ per capita solid waste production, of which $1 \%$ was mismanaged and $19 \%$ consisted of plastics [24]. We assumed a constant daily MPW generation and divided the yearly MPW production by 365 in order to obtain the daily MPW generation map (Fig. 4c).

\subsection{Modelled Output}

After a single model run, the Trash-Tracker produces for each time step a spatial distribution map of macroplastics, indicating the total mass of macroplastics present in every grid cell in the river basins. In addition, the plastic mass content of any single grid cell in the model domain can be plotted over time. For each time step in the model run, the type of plastic emissions from the river basin and the mass of emitted plastics is recorded, which can be used to produce plastics mass balance graphs. Furthermore, the Trash-Tracker registers for each time step how much of the macroplastic waste is present on land and how much is in the river. This information allows determining (the evolution of) the ratio of terrestrial versus aquatic plastic pollution. In order to get insights into the potential routes that macroplastics undertake due to wind and/or surface runoff driven transport, the Trash-Tracker records for each grid cell the number of instances that plastic trash clusters would be transported (if present) in a certain direction. This results in the potential plastics routing map, which is generated without, and is therefore independent of, the presence of plastic waste. The potential plastics routing map can be viewed as a trajectory probability map for macroplastic transport through river basins. .

9

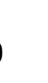

1

.

3

\section{4} 95 96 297 8 9 00 01 
a.

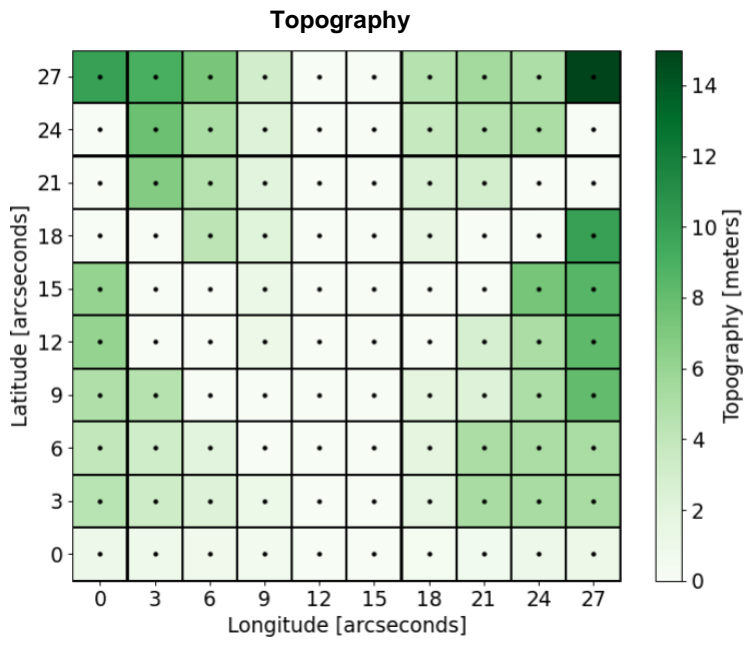

c.

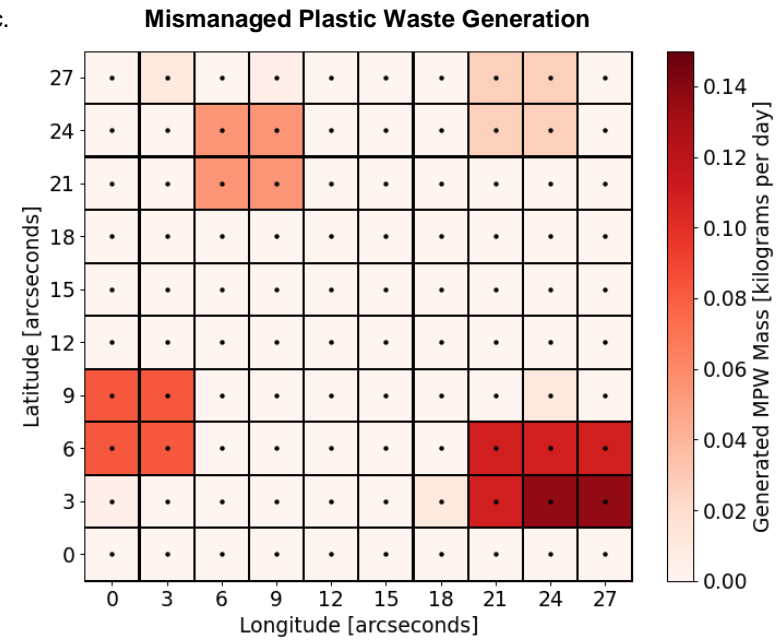

b.

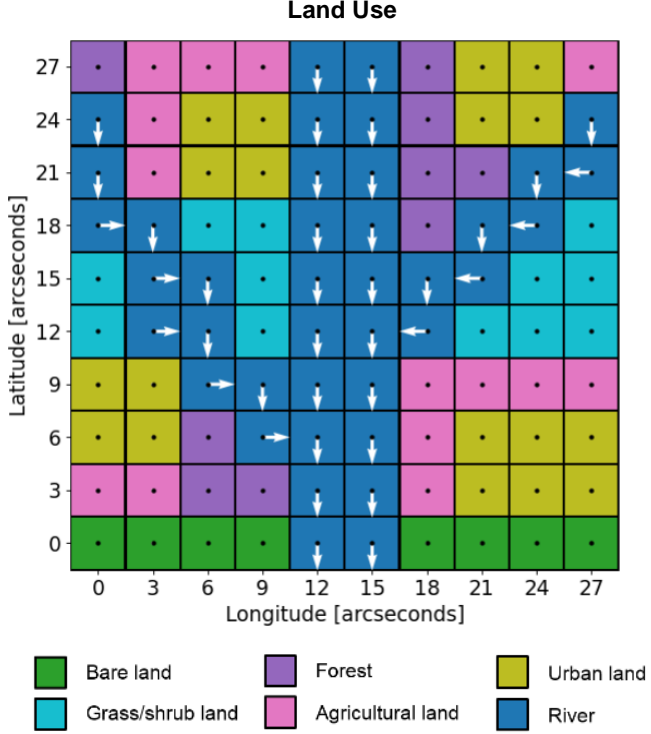

Fig. 4. Topography $(\mathrm{m})(\mathrm{a})$, land use (b) and mismanaged plastic waste generation $(\mathrm{kg} / \mathrm{d})(\mathrm{c})$ maps of the hypothetical river basin used for the model application presented in this study. White arrows in land use map indicate the river flow.

\section{Results}

\subsection{Spatiotemporal Distribution of Macroplastics}

Based on the terrain characteristics the Trash-Tracker computes a wind speed and surface runoff threshold map that depict the spatial distribution of the degree of resistance to wind and surface runoff driven mobilisation and transport of plastic waste (the threshold maps generated by the model application can be found in Supplementary Fig. SI6). The model compares for each time step the threshold maps with the wind and surface runoff conditions and computes for each time step a plastic mobilisation map. The plastic mobilisation map indicates where and by which transporting agent (wind or surface runoff) macroplastics are mobilised and transported. Temporal variations in the wind and surface runoff conditions usually lead to different plastic mobilisation maps for different time steps (Fig. 5). 
The Trash-Tracker computes the spatiotemporal distribution of macroplastics on the basis of the plastic mobilisation maps. For each modelled time step the MPW that lies on grid cells in which a threshold is surpassed will be mobilised and transported towards a neighbouring grid cell, depending on the transport direction forced by the transporting agent (wind or surface runoff). For each modelled time step spatiotemporal distribution maps that indicate the total mass of MPW present in each grid cell are generated. These maps reveal where and for how long plastic waste accumulate. Similar to how oceanic models reveal oceanic garbage patches [52], the Trash-Tracker reveals "terrestrial garbage patches", i.e. accumulation zones of plastic on land. Furthermore, the macroplastic distribution maps identify prime transportation routes of plastics and show potential locations for MPW to enter river channels. This type of information is crucial for the development of effective targeted plastic waste interception and clean-up operations that prevent plastics to enter the marine environment.

The spatiotemporal macroplastic distribution maps generated by the model application demonstrate that densely vegetated areas adjacent to urban areas usually accumulate MPW and develop as "terrestrial garbage patches" (Fig. 6a and Fig. 6b). In these hotspots the MPW content can build up to great masses until extreme weather conditions move the plastics. Even though urban areas itself are characterized by low thresholds that prevent prolonged accumulation of MPW, populated areas do show relatively high MPW masses, because they are the main source of plastic waste in the model.

The evolution of the MPW mass content can be studied on smaller scales as well. For example, Fig. $6 c$ shows the MPW mass content in a single grid cell (latitude 0 and 24 longitude) of the hypothetical river basin used in the model application. This bare land grid cell shows cycles in which it receives MPW, accumulates it for some time and eventually loses it again.

The Trash-Tracker keeps track of where the MPW is located within the river basin at all times so that, for example, the ratio between MPW on land and afloat in the river can be determined. Plastic retention in the river is not included in the model, i.e. all plastics in river grid cells follow the river flow unhindered. The graph in Fig. $6 \mathrm{~d}$ shows that in our example model application the land/river ratio is relatively constant and that on average $83 \%$ (STD: $14.5 \%$ ) of the MPW is on land. . 5 36

\section{7}

8

\section{9} 0 sit 

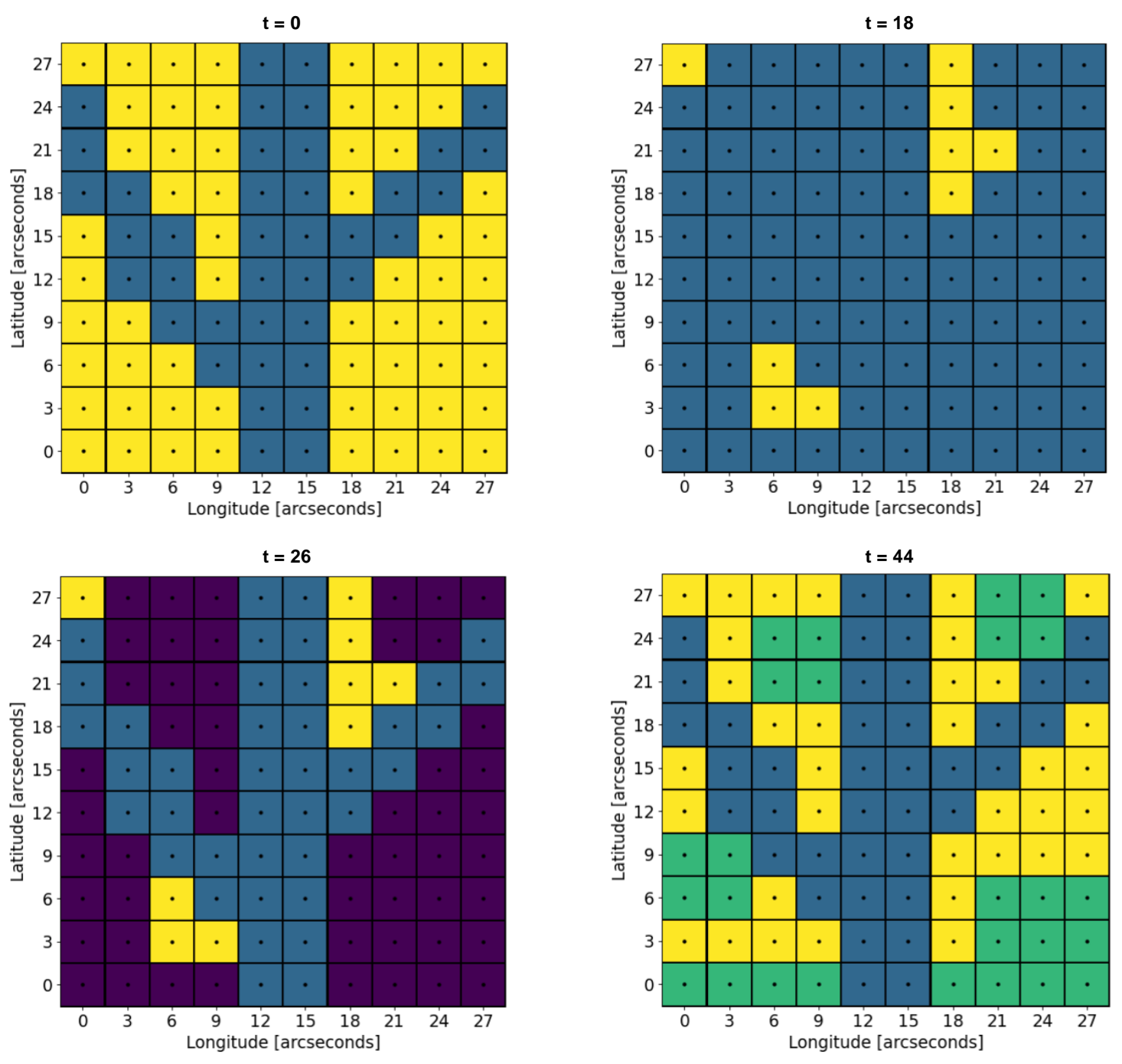

Only wind speed threshold surpassed

Only surface runoff threshold surpassed

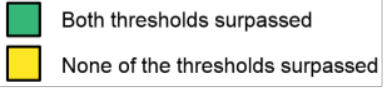

Fig. 5. Plastic mobilisation maps generated by the model application for time steps with varying weather conditions. $t=0$ : low wind and surface runoff; $t=18$ : low wind and high surface runoff; $t=26$ : high wind and low surface runoff; $t=44$ : high wind and surface runoff. 

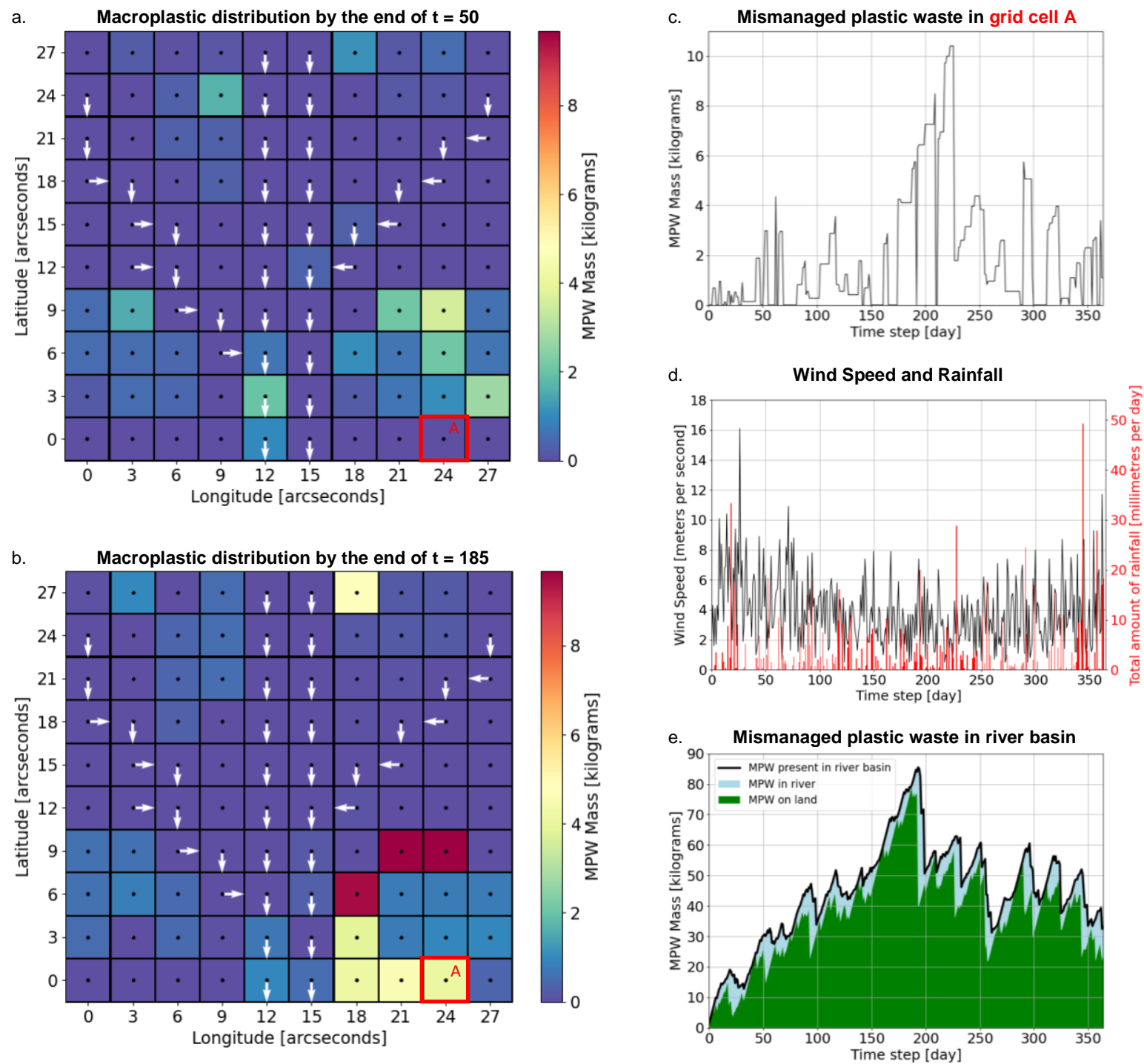

Fig. 6. Spatial distributions of macroplastics $(\mathrm{kg})$ within the hypothetical river basin generated by the model application for time steps $t=50$ (a) and $t=185$ (b). White arrows indicate river flow directions. (c) Mismanaged plastic waste mass content (kg) simulated by the model application for the bare land grid cell at latitude 0 and longitude 24 (highlighted with red box $A$ in the distribution maps). (d) Wind speed $(\mathrm{m} / \mathrm{s})$ and total amount of rainfall $(\mathrm{mm} / \mathrm{d})$ for the model application. (e) Total mismanaged plastic waste mass content $(\mathrm{kg})$ of the entire hypothetical river basin through time. Green/blue shaded areas indicate the total mass of mismanaged plastic waste in land/river grid cells, respectively.

\subsection{Potential Trajectories of Macroplastics}

For each grid cell the Trash-Tracker computes how often plastics would be transported in each of the eight possible directions under a given set of weather conditions, by comparing the wind speeds and surface runoff fluxes with the wind and surface runoff thresholds. The result of this computation is presented in a potential plastics routing map, in which the width of the arrows is proportional to the frequency with which plastic transportation was forced in that particular direction. Mismanaged plastic waste (MPW) has the highest probability to be transported in the direction with the highest frequency. Therefore the potential plastics routing map is crucial for identifying the most 


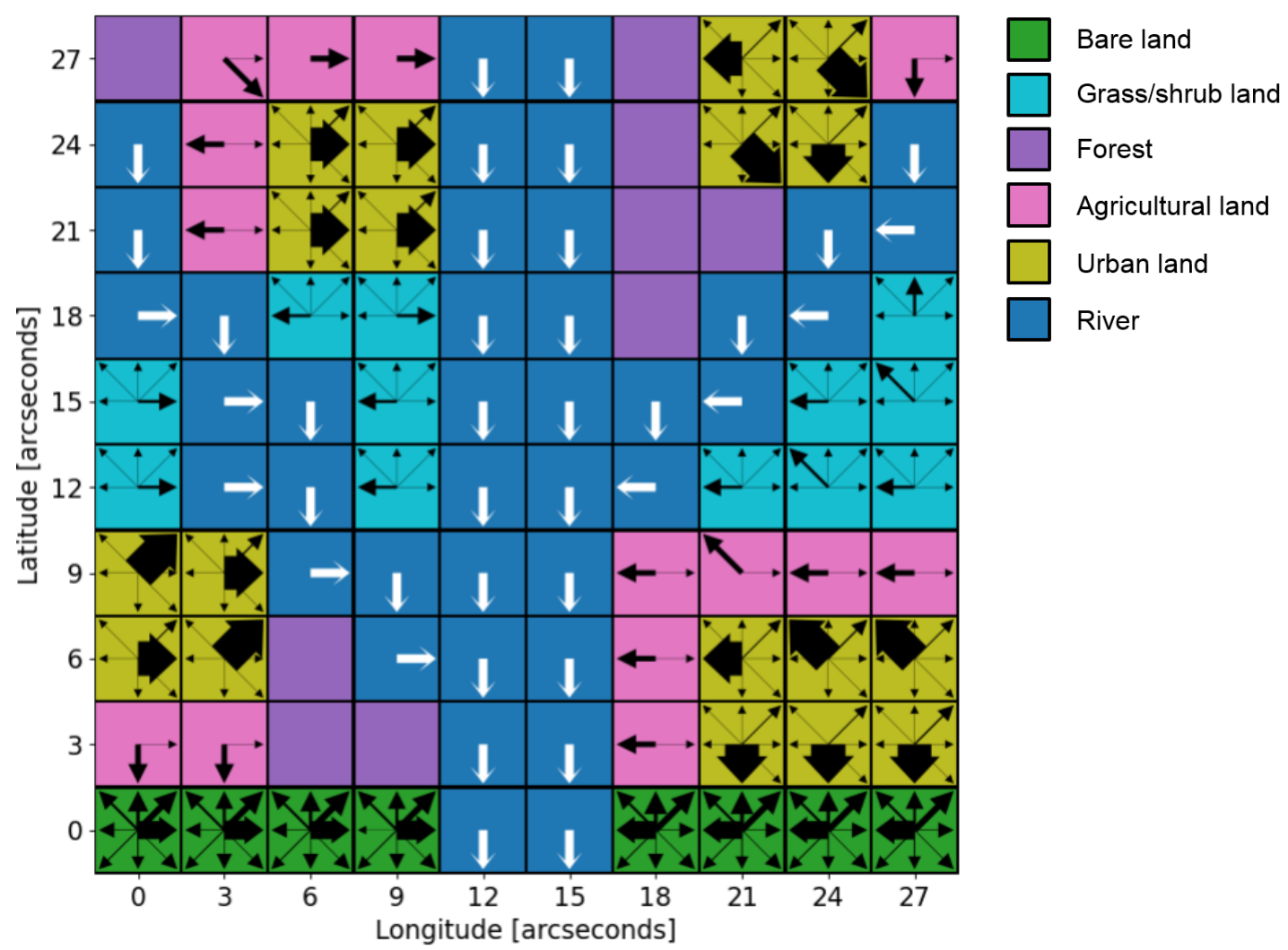

Fig. 7. Potential plastics routing map. Black arrows indicate all potential transport directions that result from the terrain characteristics, thresholds and weather conditions used for the model application described in this study. The width of the black arrow is proportional to the frequency with which plastic transport was forced in that particular direction. In river grid cells, the plastics are always transported in the direction of the river flow, indicated by white arrows in this map. The width of the white arrows is not proportional to their transport frequency. The surface roughness of forests prevents any plastic transport under the weather conditions used in this model scenario.

\subsection{Macroplastics Emissions}

The Trash-Tracker registers the plastic emissions for each time step and thereby allows for accurate river basin specific data on where and when plastics leave the river basin. This provides valuable insights on the response (time) of plastic emissions to seasonality and extreme weather conditions (e.g. floods or hurricanes) and is crucial for anticipating peak plastic discharges at river mouths. But most importantly, the spatiotemporal data on the plastics emissions of single river basins can be used as input for oceanic plastic particle tracking models.

In the model application, we found that from all the plastics that left the (hypothetical) river basin, $88.1 \%$ was emitted by the river, $5.0 \%$ by the coast (bare land in Fig. $4 \mathrm{~b}$ ) and $6.9 \%$ was moved to the adjacent river basin (landto-land emissions). These results indicate that the majority of the plastic waste is emitted to the oceans via rivers, which has been recognized by previous studies as well [36, 45, 46, 47]. 
The graph in Fig. 8 shows the total mismanaged plastic waste (MPW) input and emissions that occurred during the model application run and provides insights regarding the river basin's plastic mass budget by indicating during which periods net accumulation, i.e. MPW input $>$ MPW output, and net loss, i.e. MPW input $<$ MPW output, of plastics occur.

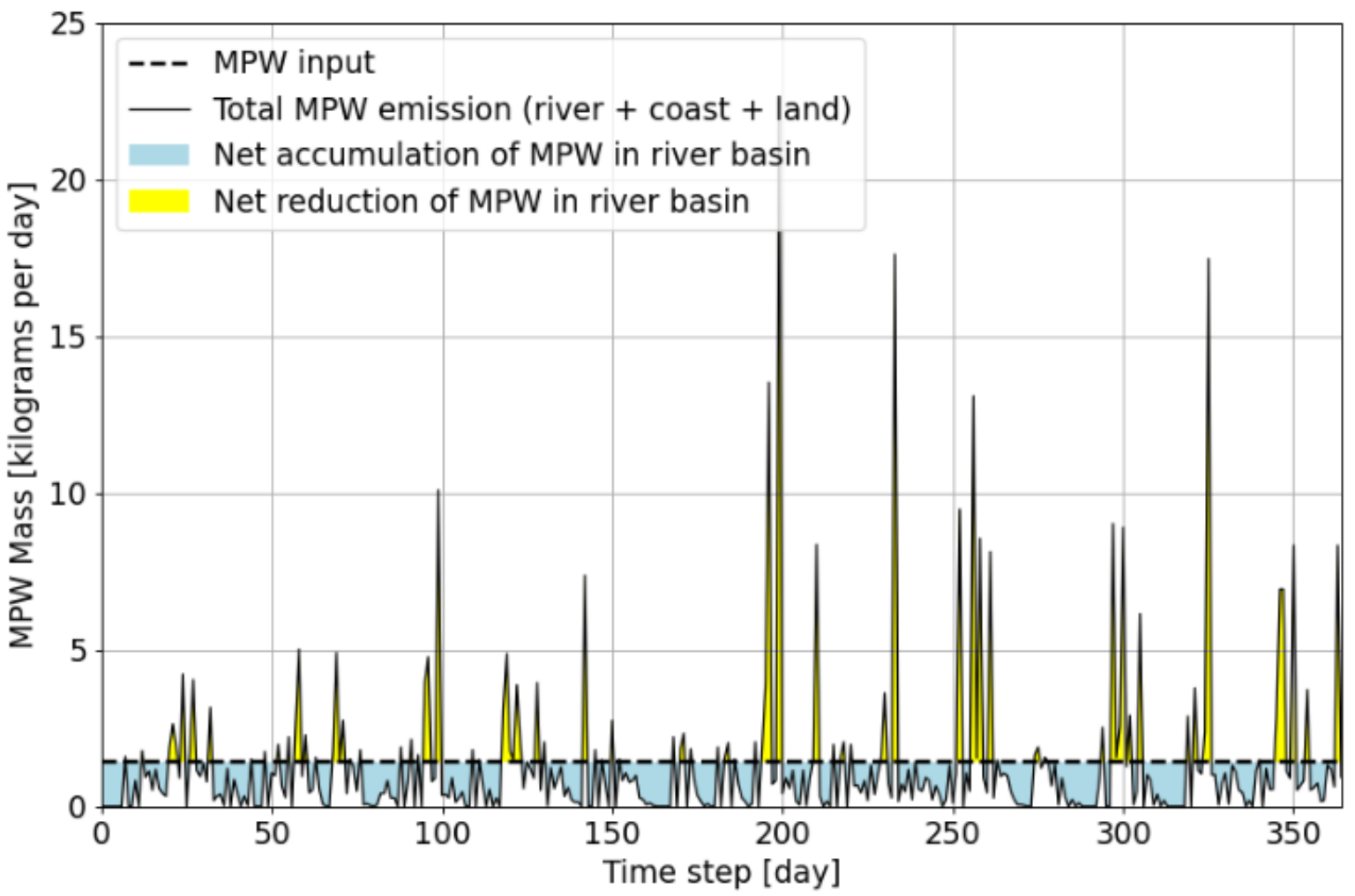

Fig. 8. Mismanaged plastic waste (MPW) input (kg) and total MPW emissions (kg) for each time step generated by the model application. The MPW emission of a time step is the sum of the river, coastal and land-to-land emissions for that time step. Light blue area indicates net MPW accumulation (MPW input > MPW output) and yellow area indicates net MPW reduction (MPW input $<$ MPW output) at the river basin scale.

\section{Discussion}

\subsection{The Trash-Tracker - an innovative new tool}

Previous studies that aimed at estimating riverine plastic emissions on the scale of single river basins, mainly focussed on the fraction of plastic waste that is emitted to the oceans and neglected what happens with the plastic between its land-based source and marine sink [23, 36]. The Trash-Tracker distinguishes itself from these studies by, for the first time, simulating the transport routes and accumulation behaviour of macroplastic waste within river basins. The modelled high resolution data of the spatiotemporal distribution of plastics within river basins exposes potential "terrestrial garbage patches" and will be fundamental for solving the global plastic waste mass budget and 
provide insights on the relative importance of terrestrial pollution with respect to freshwater and marine plastic pollution. In addition, the modelled time series on plastic emissions improve our estimates of riverine plastic input into the oceans for individual river basins and, upon upscaling, will advance the estimations on global riverine inputs.

The Trash-Tracker will find its application in the field of marine plastic pollution modelling. Marine plastic debris is transported by ocean surface currents that greatly vary in time and space [43]. Consequently, the transport and fate of marine plastic debris strongly depends on when and where plastics enter the marine environment [53]. The river basin specific time series of plastic emissions generated by the Trash-Tracker are therefore valuable input for oceanic plastic particle tracking models, improving estimations on the transport and fate of marine plastics. When the Trash-Tracker is combined with oceanic models, full global coverage can be achieved and for the first time it will be possible to track plastics all the way from source to sink. This will be fundamental for solving the global plastic mass budget and provide new insights on the fate of mismanaged plastic waste $[41,55,57]$.

Additionally, the Trash-Tracker is useful for the development of effective plastic pollution prevention, mitigation and reduction strategies. The simulated trajectories and spatiotemporal distributions can expose "terrestrial garbage patches", which allows for the design of targeted and close-to-the-source plastics interception and clean-up activities. The removal of plastic is a matter of great urgency, because it ceaselessly builds up in terrestrial, freshwater and marine environments, where they can pose a serious threat to species health and human livelihood in general $[7,10,49]$.

\subsection{Future recommendations}

\section{Modelling Plastic Transport, Distributions and Emissions}

The concept of driving forces that need to overcome thresholds appears realistic for determining whether plastics are (mobilised and) transported. However, it does not estimate how far the plastics are transported. The model restricts the displacement of plastics to one grid cell per time step, which can results in realistic macroplastic transport rates for terrestrial environments because the values of the plastic mobilisation and transport thresholds are adjusted to the spatial and temporal resolution of the model. Studies have shown that airborne microplastics can be transported over large distances, i.e. up to $95 \mathrm{~km}$ [1], but for macroplastics this has not been observed to date. The Trash-Tracker modelling framework does allow for inclusion of new formal descriptions of macroplastic transport dynamics, including airborne transport. Additionally, it allows for the improvement of current descriptions.

The Trash-Tracker simulates the transport and accumulation of plastics in rivers using a constant, 'down the drain' discharge. Hydrological processes that are known to influence plastic transport in rivers, but are not yet included in the model, are fluctuations in river discharge, flow characteristics such as the level of turbulence and tidal variations [20,47]. Additionally, vertical gradients in plastic concentrations can to develop in the water column, 
and items can be deposited on the river bed [26]. These vertical patterns could be included in the model through simple first-order removal rates, or via 3D process descriptions. Moreover, river bank vegetation, floating aquatic plants and barriers such as dams or weirs capture plastics and thereby influence the plastic emissions $[19,49,50]$. All these aspects could be included in the modelling framework, when better parametrization of the different processes would become available.

Another aspect that is difficult to parameterize is the influence of anthropogenic structures and activities on plastic accumulation and transport. For example, plastic waste that clogs sewerage systems in urban areas [31, 56], or large scale clean-up activities such as the World Cleanup Day, which in 2019 united more than 20 million people in 180 countries that collected $>77,000$ plastic trash items [58]. Future research could explore the possibility of adding anthropogenic activities to the model in order to improve the estimates on macroplastic transport, removal and retention within river basins.

\section{Model Calibration and Validation}

The Trash-Tracker is a first spatiotemporal explicit framework that models both terrestrial and riverine transport of macroplastic. However, there are still many uncertainties associated with the accuracy of the model parameterization and prediction, because data is scarce. Emissions, mobilisation and transport thresholds and transport pathways of plastic waste within actual river basins should be (empirically) determined. For example, physical experiments (e.g. on artificial hillslopes) can elucidate under which wind and surface runoff conditions different types of macroplastics are mobilised and transported over terrains with varying combinations of slopes and land use. These experiments would offer valuable insights on the influence of material properties of the plastic waste items (e.g. size, shape, density, wet/dry, etc.) on the mobilisation and transport thresholds [37].

Once the Trash-Tracker contains empirically proven mobilisation and transport thresholds, the model predictions would ideally be calibrated and validated with observational data. The modelled macroplastic waste distribution on land and in the rivers can be compared with actual macroplastic distribution data; quantified by e.g. field plastic collection efforts [48], citizen litter collection projects [42], or optical satellite data [5]. Riverine plastics transport can be quantified with visual counting or automated methods such as unmanned aerial vehicles [11] and cameras [51]. We anticipate that future collaborations with field collection and monitoring projects allow for a fast and robust calibration of the Trash-Tracker and improve the validity of the forecasted transport and fate of macroplastics within river basins. 


\section{Conclusions}

492

Each day vast amounts of mismanaged plastic waste (MPW) enter the natural environment. Although various studies have examined where and when MPW is generated and emitted, the actual trajectory between land-based source and marine sink remained largely unresolved. For this reason we developed the Trash-Tracker, a numerical modelling framework that simulates specific spatiotemporal distributions and trajectories of macroplastic waste resulting from wind and surface runoff driven transport on the river basin scale. This model contributes to improving our fundamental understanding of the mobilisation, transport and accumulation behaviour of macroplastics over land. The spatiotemporal distribution maps indicate the locations of "terrestrial garbage patches", which allows for the development of targeted clean-up strategies that effectively remove plastics from the terrestrial environment. In addition, the potential plastic routing maps identify prime transportation routes of plastic waste through river basins, which is crucial for designing close-to-the-source interception strategies that prevents plastics from entering the marine environment.

\section{List of abbreviations}

MPW mismanaged plastic waste

W $\quad$ wind speed $(\mathrm{m} / \mathrm{s})$

Whres $\quad$ wind speed threshold for macroplastic mobilisation and transport $(\mathrm{m} / \mathrm{s})$

SR Surface runoff $(\mathrm{mm} / \mathrm{d})$

$S R_{\text {thres }} \quad$ surface runoff threshold for macroplastic mobilisation and transport $(\mathrm{mm} / \mathrm{d})$

\section{Declarations}

\section{Availability of data and materials}

All data used in this study are included in this published article and its supplementary information files. The Trash-Tracker is a code written in Python in the open-source web application Jupyter Notebook. The code of the Trash-Tracker (v1.0.2) and the user's manual are available at http://doi.org/10.5281/zenodo.4546247.

\section{Competing interests}

The authors declare that they have no competing interests. 


\section{Funding}

The work of Tim van Emmerik is part of the Veni research programme The River Plastic Monitoring Project with project number 18211, which is (partly) financed by the Dutch Research Council (NWO). Charlotte Laufkötter acknowledges financial support from the Swiss National Science Foundation under grant 174124. Helge Niemann received funding through the European Research Council (ERC-CoG Grant No. 772923, project VORTEX).

\section{Authors' contributions}

Conceptualisation: YM, TvE; Methodology: YM, TvE; Software: YM; Validation: YM, TvE; Formal analysis: YM, TvE, MK, CL; Investigation: YM; Data curation: YM; Writing - original draft: YM; Writing - review \& editing: YM, TvE, MK, CL, HN; Visualisation: YM; Supervision: TvE, HN; Project administration: YM; Funding acquisition: TvE. All authors read and approved the final manuscript.

\section{Acknowledgements}

Not applicable.

\section{References}

1. Allen S, Allen D, Phoenix VR, Le Roux G, Durántez Jiménez P, Simonneau A, et al. Atmospheric transport and deposition of microplastics in a remote mountain catchment. Nat Geosci. 2019;12(5):339-44 http://dx.doi.org/10.1038/s41561-019-0335-5.

2. Anaconda Software Distribution. Computer software. Vers. 2-2.4.0. Anaconda. 2016. https://anaconda.com.

3. Barboza LGA, Cózar A, Gimenez BCG, Barros TL, Kershaw PJ, Guilhermino L. Macroplastics Pollution in the Marine Environment. In: World Seas: an Environmental Evaluation. London: Academic Press; 2019. p. 30528. http://dx.doi.org/10.1016/B978-0-12-805052-1.00019-X.

4. Bartholomé E, Belward AS. GLC2000: a new approach to global land cover mapping from Earth observation data. Int J Remote Sens. 2005;26(9):1959-77 http://dx.doi.org/10.1080/01431160412331291297.

5. Biermann L, Clewley D, Martinez-Vicente V, Topouzelis K. Finding plastic patches in coastal waters using optical satellite data. Sci Rep. 2020;10(1):5364 http://dx.doi.org/10.1038/s41598-020-62298-z.

6. Borrelle SB, Ringma J, Law KL, Monnahan CC, Lebreton L, McGivern A, et al. Predicted growth in plastic waste exceeds efforts to mitigate plastic pollution. Science. 2020;369(6510):1515-8 http://dx.doi.org/10.1126/science.aba3656.

7. Bucci K, Tulio M, Rochman CM. What is known and unknown about the effects of plastic pollution: A metaanalysis and systematic review. Ecol Appl. 2020;30(2):e02044 http://dx.doi.org/10.1002/eap.2044. 
8. Delandmeter P, van Sebille E. The Parcels v2.0 Lagrangian framework: new field interpolation schemes. Geosci Model Dev. 2019;12(8):3571-84 http://dx.doi.org/10.5194/gmd-12-3571-2019.

9. ESA. Land Cover CCl Product User Guide Version 2.0. Tech. Rep. 2017. maps.elie.ucl.ac.be/CCl/viewer/download/ESACCl-LC-Ph2-PUGv2 2.0.pdf.

10. Everaert G, De Rijcke M, Lonneville B, Janssen CR, Backhaus T, Mees J, et al. Risks of floating microplastic in the global ocean. Environ Pollut. 2020;267(115499):115499 http://dx.doi.org/10.1016/j.envpol.2020.115499.

11. Geraeds M, van Emmerik $T$, de Vries R, bin Ab Razak MS. Riverine plastic litter monitoring using Unmanned Aerial Vehicles (UAVs). Remote Sens (Basel). 2019;11(17):2045 http://dx.doi.org/10.3390/rs11172045.

12. Geyer R, Jambeck JR, Law KL. Production, use, and fate of all plastics ever made. Sci Adv. 2017;3(7):e1700782 http://dx.doi.org/10.1126/sciadv.1700782.

13. Ghiggi G, Humphrey V, Seneviratne SI, Gudmundsson L. GRUN: an observation-based global gridded runoff dataset from 1902 to 2014. Earth Syst Sci Data. 2019;11(4):1655-74 http://dx.doi.org/10.5194/essd-11-1655$\underline{2019}$.

14. Global Wind Atlas 3.0, a free, web-based application developed, owned and operated by the Technical University of Denmark (DTU). The Global Wind Atlas 3.0 is released in partnership with the World Bank Group, utilizing data provided by Vortex, using funding provided by the Energy Sector Management Assistance Program (ESMAP). https://globalwindatlas.info.

15. Goel MK. Runoff coefficient. In: Encyclopedia of Snow, Ice and Glaciers. Dordrecht: Springer; 2011. p. 9523. http://dx.doi.org/10.1007/978-90-481-2642-2 456.

16. Hardesty BD, Harari J, Isobe A, Lebreton L, Maximenko N, Potemra J, et al. Using numerical model simulations to improve the understanding of micro-plastic distribution and pathways in the marine environment. Front Mar Sci. 2017;4 http://dx.doi.org/10.3389/fmars.2017.00030.

17. Jenson SK, Domingue JO. Extracting topographic structure from digital elevation data for geographic information system analysis. American Society for Photogrammetry and Remote Sensing. 1988;54(11):1593600.

18. Karamage F, Zhang C, Fang X, Liu T, Ndayisaba F, Nahayo L, et al. Modeling rainfall-runoff response to land use and land cover change in Rwanda (1990-2016). Water (Basel). 2017;9(2):147 http://dx.doi.org/10.3390/w9020147.

19. Kooi M, Besseling E, Kroeze C, van Wezel AP, Koelmans AA. Modeling the fate and transport of plastic debris in freshwaters: Review and guidance. In: The Handbook of Environmental Chemistry. Cham: Springer International Publishing; 2018. p. 125-52 http://dx.doi.org/10.1007/978-3-319-61615-5 7. 
20. Kurniawan SB, Imron MF. The effect of tidal fluctuation on the accumulation of plastic debris in the Wonorejo River Estuary, Surabaya, Indonesia. Environ technol innov. 2019;15(100420):100420 http://dx.doi.org/10.1016/j.eti.2019.100420.

21. Lau WWY, Shiran Y, Bailey RM, Cook E, Stuchtey MR, Koskella J, et al. Evaluating scenarios toward zero plastic pollution. Science. 2020;369(6510):1455-61 http://dx.doi.org/10.1126/science.aba9475.

22. Lebreton LCM, Greer SD, Borrero JC. Numerical modelling of floating debris in the world's oceans. Mar Pollut Bull. 2012;64(3):653-61 http://dx.doi.org/10.1016/j.marpolbul.2011.10.027.

23. Lebreton LCM, van der Zwet J, Damsteeg J-W, Slat B, Andrady A, Reisser J. River plastic emissions to the world's oceans. Nat Commun. 2017;8(1):15611 http://dx.doi.org/10.1038/ncomms15611.

24. Lebreton LCM, Andrady A. Future scenarios of global plastic waste generation and disposal. Palgrave Commun. 2019;5(1):1-11 http://dx.doi.org/10.1057/s41599-018-0212-7.

25. Lehner B, Verdin KL, Jarvis A. New global hydrography derived from spaceborne elevation data. Eos, Transactions, American Geophysical Union. 2008;89(10):93-4 http://dx.doi.org/10.1029/2008EO100001.

26. Lenaker PL, Baldwin AK, Corsi SR, Mason SA, Reneau PC, Scott JW. Vertical distribution of microplastics in the water column and surficial sediment from the Milwaukee River basin to Lake Michigan. Environ Sci Technol. 2019;53(21):12227-37 http://dx.doi.org/10.1021/acs.est.9b03850.

27. Materić D, Kasper-Giebl A, Kau D, Anten M, Greilinger M, Ludewig E, et al. Micro-and Nanoplastics in Alpine Snow: A New Method for Chemical Identification and (Semi) Quantification in the Nanogram Range. Environmental Science \& Technology. 2020;54(4):2353-9 http://dx.doi.org/10.1021/acs.est.9b07540.

28. Maximenko N, Hafner J, Niiler P. Pathways of marine debris derived from trajectories of Lagrangian drifters. Mar Pollut Bull. 2012;65(1-3):51-62 http://dx.doi.org/10.1016/j.marpolbul.2011.04.016.

29. Meijer L, van Emmerik T, Lebreton L, Schmidt C, van der Ent R. Over 1000 rivers accountable for $80 \%$ of global riverine plastic emissions into the ocean. EarthArXiv. 2019 http://dx.doi.org/10.31223/osf.io/zjgty.

30. Met Office. National Meteorological Library and Archive Fact sheet 6 - The Beaufort Scale. 2010. https://web.archive.org/web/20121002134429/http://www.metoffice.gov.uk/media/pdf/4/4/Fact Sheet No. 6 - Beaufort Scale.pdf.

31. Njeru J. The urban political ecology of plastic bag waste problem in Nairobi, Kenya. Geoforum. 2006;37(6):1046-58 http://dx.doi.org/10.1016/j.geoforum.2006.03.003.

32. Ribeiro F, Okoffo ED, O'Brien JW, Fraissinet-Tachet S, O'Brien S, Gallen M, et al. Quantitative analysis of selected plastics in high-commercial-value Australian seafood by pyrolysis gas chromatography mass spectrometry. Environ Sci Technol. 2020;54(15):9408-17 http://dx.doi.org/10.1021/acs.est.0c02337.

33. Royal Netherlands Meteorological Institute (KNMI). Daggegevens van het weer in Nederland, RH, Etmaalsom van de neerslag (in $0.1 \mathrm{~mm})(-1$ voor <0.05 mm). http://projects.knmi.nl/klimatologie/daggegevens/selectie.cgi. Accessed 29 May 2020. 
34. Royal Netherlands Meteorological Institute (KNMI). Frequentietabellen Windsnelheid in m/s, Distributief in procenten, De Bilt. http://projects.knmi.nl/klimatologie/frequentietabellen/maand.cgi. Accessed 29 May 2020.

35. Royal Netherlands Meteorological Institute (KNMI). Frequentietabellen Windrichting in graden, Distributief in procenten, De Bilt. http://projects.knmi.nl/klimatologie/frequentietabellen/maand.cgi. Accessed 29 May 2020.

36. Schmidt C, Krauth T, Wagner S. Export of plastic debris by rivers into the sea. Environ Sci Technol. 2017;51(21):12246-53 http://dx.doi.org/10.1021/acs.est.7b02368.

37. Schwarz AE, Ligthart TN, Boukris E, van Harmelen T. Sources, transport, and accumulation of different types of plastic litter in aquatic environments: A review study. Mar Pollut Bull. 2019;143:92-100 http://dx.doi.org/10.1016/j.marpolbul.2019.04.029.

38. ShiChun Z, MeiXia P, HongYa Z, Li D, YongJun T, JianGuo D, et al. Situation and harm of micro-nano plastic pollution in seafood. Journal of Food Safety and Quality. 2019;10(9):2689-96.

39. Shields A. Application of similarity principles and turbulence research to bed-load movement. 1936.

40. Sigler M. The effects of plastic pollution on aquatic wildlife: Current situations and future solutions. Water Air Soil Pollut. 2014;225(11) http://dx.doi.org/10.1007/s11270-014-2184-6.

41. Stephens M. The search for the missing plastic. Phys World. 2020;33(5):40-4 http://dx.doi.org/10.1088/2058$\underline{7058 / 33 / 5 / 30}$

42. Syberg K, Palmqvist A, Khan FR, Strand J, Vollertsen J, Clausen LPW, et al. A nationwide assessment of plastic pollution in the Danish realm using citizen science. Sci Rep. 2020;10(1):17773 http://dx.doi.org/10.1038/s41598-020-74768-5.

43. Talley LD, Pickard GL, Emery WJ, Swift JH. Descriptive Physical Oceanography: An Introduction. 6th ed. London: Academic Press; 2011.

44. Tramoy R, Gasperi J, Colasse L, Silvestre M, Dubois P, Noûs C, et al. Transfer dynamics of macroplastics in estuaries - New insights from the Seine estuary: Part 2. Short-term dynamics based on GPS-trackers. Marine Pollution Bulletin. 2020;160:111566 http://dx.doi.org/10.1016/j.marpolbul.2020.111566.

45. van Calcar CJ, van Emmerik T. Abundance of plastic debris across European and Asian rivers. Environ Res Lett. 2019;14(12):124051 http://dx.doi.org/10.1088/1748-9326/ab5468.

46. van Emmerik T, Loozen M, van Oeveren K, Buschman F, Prinsen G. Riverine plastic emission from Jakarta into the ocean. Environ Res Lett. 2019;14(8):084033 http://dx.doi.org/10.1088/1748-9326/ab30e8.

47. van Emmerik T, Tramoy R, van Calcar C, Alligant S, Treilles R, Tassin B, et al. Seine plastic debris transport tenfolded during increased river discharge. Front Mar Sci. 2019;6:642 http://dx.doi.org/10.3389/fmars.2019.00642.

48. van Emmerik T, Vriend P, Roebroek J. An evaluation of the River-OSPAR method for quantifying macrolitter on Dutch riverbanks. Wageningen: Wageningen University. 2020;86 p. http://dx.doi.org/10.18174/519776.

49. van Emmerik T, Schwarz A. Plastic debris in rivers. WIREs Water. 2020. http://dx.doi.org/10.1002/wat2.1398. 
50. van Emmerik T, Roebroek C, de Winter W, Vriend P, Boonstra M, Hougee M. Riverbank macrolitter in the Dutch Rhine-Meuse delta. Environ Res Lett. 2020;15(10):104087 http://dx.doi.org/10.1088/17489326/abb2c6.

51. van Lieshout C, van Oeveren K, van Emmerik T, Postma E. Automated river plastic monitoring using deep learning and cameras. Earth Space Sci. 2020;7(8) http://dx.doi.org/10.1029/2019ea000960.

52. van Sebille E, England MH, Froyland G. Origin, dynamics and evolution of ocean garbage patches from observed surface drifters. Environ Res Lett. 2012;7(4):044040 http://dx.doi.org/10.1088/1748$\underline{9326 / 7 / 4 / 044040 .}$

53. van Sebille E, Aliani S, Law KL, Maximenko N, Alsina JM, Bagaev A, et al. The physical oceanography of the transport of floating marine debris. Environ Res Lett. 2020;15(2):023003 http://dx.doi.org/10.1088/17489326/ab6d7d

54. Vethaak AD, Leslie HA. Plastic debris is a human health issue. Environ Sci Technol. 2016;50(13):6825-6 http://dx.doi.org/10.1021/acs.est.6b02569.

55. Wayman $\mathrm{C}$, Niemann $\mathrm{H}$. The fate of plastic in the ocean environment - a minireview. Environ Sci Process Impacts. 2021 http://dx.doi.org/10.1039/d0em00446d.

56. Windsor FM, Durance I, Horton AA, Thompson RC, Tyler CR, Ormerod SJ. A catchment-scale perspective of plastic pollution. Glob Chang Biol. 2019;25(4):1207-21 http://dx.doi.org/10.1111/gcb.14572.

57. Woodall LC, Sanchez-Vidal A, Canals M, Paterson GLJ, Coppock R, Sleight V, et al. The deep sea is a major sink for microplastic debris. R Soc Open Sci. 2014;1(4):140317 http://dx.doi.org/10.1098/rsos.140317.

58. World Cleanup Day. https://www.worldcleanupday.org/. Accessed 21 December 2020. . $a^{2}$ 3

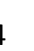
85 66 a

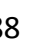
a

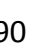
1 


\title{
Supplementary Information for "The Trash-Tracker: A Macroplastic Transport and Fate Model at River Basin Scale"
}

\author{
Y.A.M. Mellink ${ }^{1,2}$, T.H.M. van Emmerik ${ }^{1}$, M. Kooi ${ }^{3}$, C. Laufkötter ${ }^{4,5}$, and H. Niemann'6,2,7
}

${ }^{1}$ Hydrology and Quantitative Water Management Group, Wageningen University, Wageningen, the Netherlands

${ }^{2}$ Department of Earth Sciences, Faculty of Geosciences, Utrecht University, Utrecht, the Netherlands

${ }^{3}$ Aquatic Ecology and Water Quality Group, Wageningen University, Wageningen, the Netherlands

${ }^{4}$ Climate and Environmental Physics, Physics Institute, University of Bern, Bern, Switzerland

${ }^{5}$ Oeschger Centre for Climate Change Research, University of Bern, Bern, Switzerland

${ }^{6}$ Department of Marine Microbiology and Biogeochemistry, NIOZ Royal Netherlands Institute for Sea Research, 't Horntje, the Netherlands

${ }^{7}$ CAGE - Centre for Arctic Gas Hydrate, Environment and Climate, Department of Geosciences, UiT The Arctic University of Norway, Tromsø, Norway

\section{S1. Table wind speed and surface runoff thresholds}

Tab. Sl1. Wind speed $\left(W_{\text {thres }}\right)$ and surface runoff threshold $\left(S R_{\text {thres }}\right)$ values used by the Trash-Tracker. These values indicate for each combination of land use and terrain slope, the critical wind speed $(\mathrm{m} / \mathrm{s})$ and surface runoff $(\mathrm{mm} / \mathrm{d})$ presumed to mobilise and transport macroplastics. $\mathrm{R} x-\mathrm{y}$ refers to the surface runoff threshold for downhill slopes with a slope angle between $\mathrm{x}$ and $\mathrm{y}$ degrees. For uphill slopes the surface runoff threshold for all land use types is $1000 \mathrm{~mm} / \mathrm{d}$.

River

Urban land

Bare land

Grass/shrub land

Agricultural land

Forest

\begin{tabular}{|c|c|c|c|c|c|c|c|c|c|c|c|}
\hline \multicolumn{3}{|c|}{$\begin{array}{l}\text { Wind speed threshold, } W_{\text {thres }} \text {, in } \\
\text { meters per second }\end{array}$} & \multicolumn{9}{|c|}{ Surface runoff threshold, $S R_{\text {thres }}$, in millimetres per day } \\
\hline Flat terrain & radian uphill $^{1}$ & radian downhill $^{1}$ & $R_{0}-10$ & $R_{10-20}$ & $R_{20-30}$ & $R_{30-40}$ & $R_{40-50}$ & $R_{50-60}$ & $R_{60-70}$ & $R_{70-80}$ & $R_{80-90}$ \\
\hline 30.0 & $\mathrm{n} / \mathrm{a}$ & $\mathrm{n} / \mathrm{a}$ & 0.00 & 0.00 & 0.00 & 0.00 & 0.00 & 0.00 & 0.00 & 0.00 & 0.00 \\
\hline 8.8 & +4.2 & -4.2 & 2.00 & 1.75 & 1.50 & 1.25 & 1.00 & 0.75 & 0.50 & 0.25 & 0.001 \\
\hline 6.6 & +4.2 & -4.2 & 3.00 & 2.75 & 2.50 & 2.25 & 2.00 & 1.75 & 1.50 & 1.25 & 1.00 \\
\hline 10.0 & +4.2 & -4.2 & 4.00 & 3.75 & 3.50 & 3.25 & 3.00 & 2.75 & 2.50 & 2.25 & 2.00 \\
\hline 13.2 & +4.2 & -4.2 & 5.00 & 4.75 & 4.50 & 4.25 & 4.00 & 3.75 & 3.50 & 3.25 & 3.00 \\
\hline 26.4 & +4.2 & -4.2 & 7.00 & 6.75 & 6.50 & 6.25 & 6.00 & 5.75 & 5.50 & 5.25 & 5.00 \\
\hline
\end{tabular}

\section{S2. Wind directions conversion table}

Tab. SI2. Wind directions conversion table from degrees to the eight main directions used in the model. Wind direction is defined as where the wind originates from. The third column in this table indicates the direction in which plastics carried by the wind are transported, this direction is always opposite of the direction from which the wind originates. 


\begin{tabular}{l|c|c} 
Wind direction [degrees] & Wind direction & Direction of wind driven particle transport \\
\hline $292.5^{\circ}-337.5^{\circ}$ & $\mathrm{NW}$ & $\mathrm{SE}$ \\
$337.5^{\circ}-22.5^{\circ}$ & $\mathrm{N}$ & $\mathrm{S}$ \\
$22.5^{\circ}-67.5^{\circ}$ & $\mathrm{NE}$ & $\mathrm{SW}$ \\
$67.5^{\circ}-112.5^{\circ}$ & $\mathrm{E}$ & $\mathrm{W}$ \\
$112.5^{\circ}-157.5^{\circ}$ & $\mathrm{SE}$ & $\mathrm{NW}$ \\
$157.5^{\circ}-202.5^{\circ}$ & $\mathrm{S}$ & $\mathrm{N}$ \\
$202.5^{\circ}-247.5^{\circ}$ & $\mathrm{SW}$ & $\mathrm{NE}$ \\
$247.5^{\circ}-292.5^{\circ}$ & $\mathrm{W}$ & $\mathrm{E}$
\end{tabular}

- What is the overland transport probability per kilometre for land use type 'bare land'?

- What is the overland transport probability per kilometre for land use type 'urban'?

- What is the overland transport probability per kilometre for land use type 'agricultural land'?

- What is the overland transport probability per kilometre for land use type 'forest'?

Averaging their answers gave probabilities of $0.96,0.75,0.44$ and 0.17 for bare, urban, agricultural and forest lands, respectively. We roughly interpreted these average probabilities as $1.00,0.75,0.50$ and 0.25 and determined the wind thresholds for urban, agricultural and forest lands by multiplying 6.6 with the reciprocals of the average probability values (Fig. SI1). As no probability of plastic transport estimates were available for grass/shrublands, we took a value between 8.8 and $13.2 \mathrm{~m} / \mathrm{s}: 10.0 \mathrm{~m} / \mathrm{s}$. 


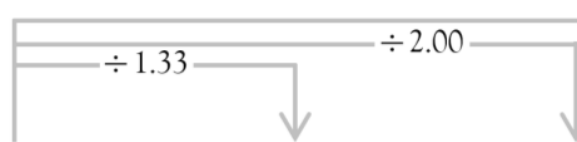

Average probability

Land use type

Wind speed threshold

748
Bare land

0.75

0.50

Urban land

Agricultural land

Forest

$6.6 \mathrm{~m} / \mathrm{s}$

$8.8 \mathrm{~m} / \mathrm{s}$

$13.2 \mathrm{~m} / \mathrm{s}$

$26.4 \mathrm{~m} / \mathrm{s}$

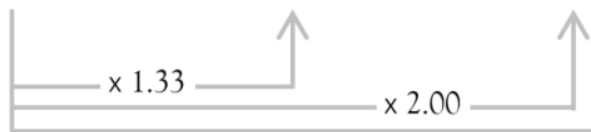

${ }^{*}$ Average of the probability estimates from experts (see Table S9 in Supplementary Materials Meijer et al. [3])

Fig. SI1. Schematic representation of the extrapolation calculations of the wind thresholds, from (flat) 'Bare land' (6.6 m/s) to the 'Urban land', 'Agricultural land' and 'Forest' land use types. The multiplication factors are the reciprocals of the average probability estimates of plastic transport for these four types of land use as predicted by a panel of experts [3].

\section{S4. Map of the directions and magnitude of the steepest downhill slopes for the model application}
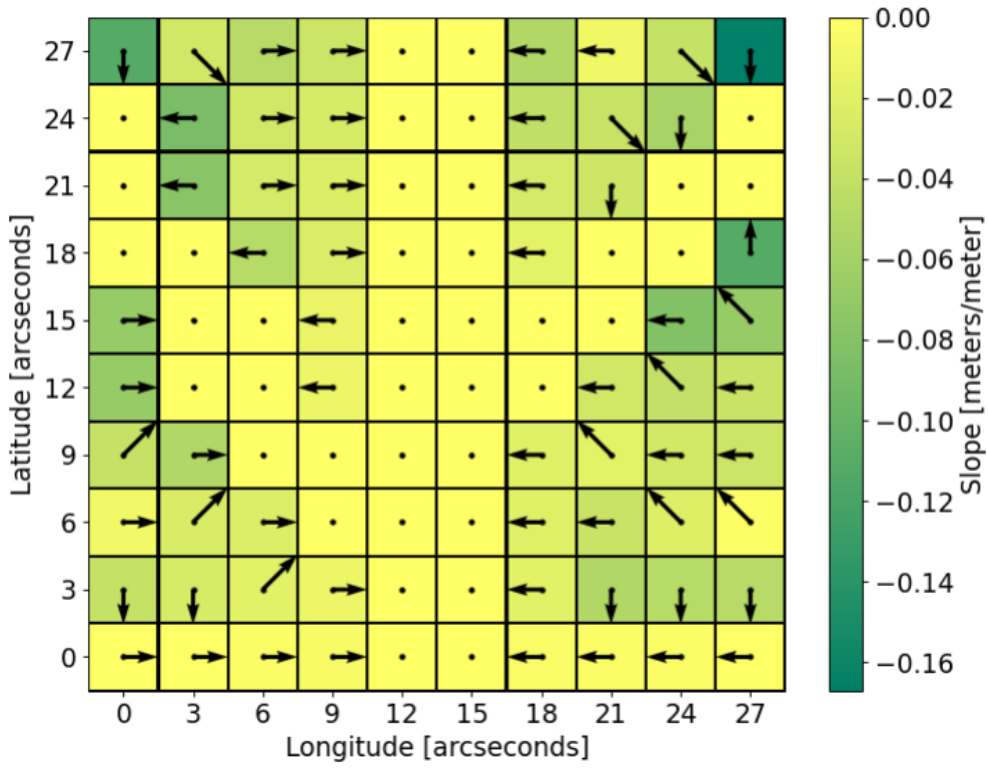

Fig. SI2. Direction and magnitude $(\mathrm{m} / \mathrm{m})$ of the steepest downhill slope for each grid cell as computed from the topography map of the hypothetical river basin used in the model application. In the hypothetical river basin all steepest slopes are downhill and therefore only negative slope values occur. 


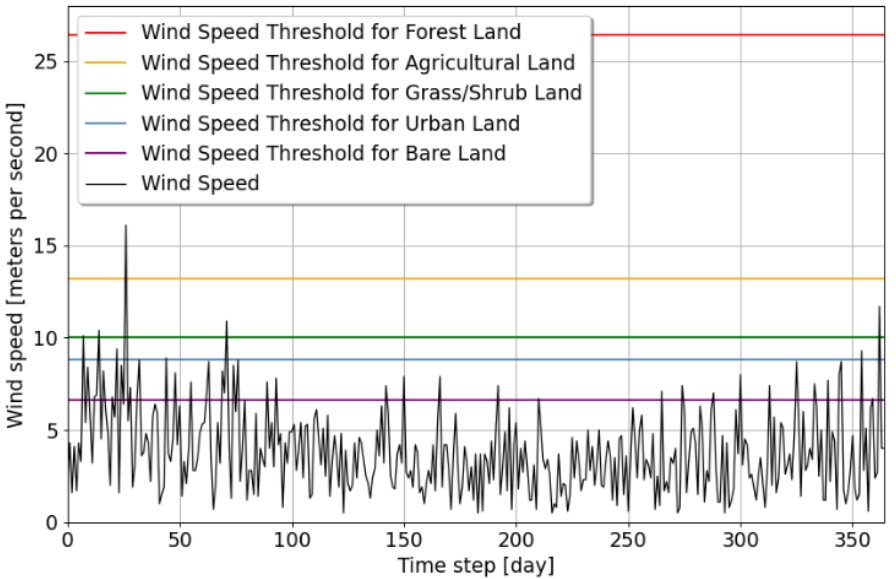

Fig. SI3. Wind speed $(\mathrm{m} / \mathrm{s})$ for every time step in the model application, along with the wind speed threshold values $(\mathrm{m} / \mathrm{s})$ for flat 


\section{S6. Table wind directions for the model application}

793 Tab. SI3. Wind directions, defined as the direction from which it originates, for each time step in the model application. Note that

794 plastics carried by the wind are transported in the opposite direction as from where the wind originates.

\begin{tabular}{|c|c|}
\hline 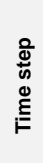 & 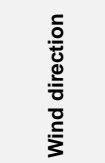 \\
\hline 0 & south \\
\hline 1 & southwest \\
\hline 2 & northeast \\
\hline 3 & east \\
\hline 4 & west \\
\hline 5 & south \\
\hline 6 & east \\
\hline 7 & southwest \\
\hline 8 & west \\
\hline 9 & southwest \\
\hline 10 & south \\
\hline 11 & west \\
\hline 12 & southwest \\
\hline 13 & southeast \\
\hline 14 & southeast \\
\hline 15 & southwest \\
\hline 16 & southeast \\
\hline 17 & southeast \\
\hline 18 & southeast \\
\hline 19 & southwest \\
\hline 20 & northeast \\
\hline 21 & east \\
\hline 22 & northwest \\
\hline 23 & north \\
\hline 24 & north \\
\hline 25 & south \\
\hline 26 & west \\
\hline 27 & southwest \\
\hline 28 & northeast \\
\hline 29 & southwest \\
\hline 30 & north \\
\hline 31 & southwest \\
\hline 32 & north \\
\hline 33 & southwest \\
\hline 34 & south \\
\hline 35 & east \\
\hline 36 & south \\
\hline 37 & southwest \\
\hline 38 & northeast \\
\hline 39 & northeast \\
\hline 40 & northwest \\
\hline 41 & southwest \\
\hline 42 & east \\
\hline 43 & southwest \\
\hline 44 & southwest \\
\hline 45 & east \\
\hline 46 & southwest \\
\hline 47 & south \\
\hline 48 & southwest \\
\hline 49 & east \\
\hline 50 & west \\
\hline 51 & southwest \\
\hline 52 & south \\
\hline 53 & northwest \\
\hline 54 & west \\
\hline 55 & south \\
\hline 56 & west \\
\hline 57 & southeast \\
\hline 58 & northeast \\
\hline 59 & northwest \\
\hline 60 & northeast \\
\hline 61 & northeast \\
\hline
\end{tabular}

\begin{tabular}{|c|c|}
\hline 62 & southwest \\
\hline 63 & southwest \\
\hline 64 & south \\
\hline 65 & northwest \\
\hline 66 & north \\
\hline 67 & northeast \\
\hline 68 & southeast \\
\hline 69 & southwest \\
\hline 70 & southeast \\
\hline 71 & east \\
\hline 72 & south \\
\hline 73 & southwest \\
\hline 74 & southeast \\
\hline 75 & southwest \\
\hline 76 & southwest \\
\hline 77 & west \\
\hline 78 & southwest \\
\hline 79 & southwest \\
\hline 80 & west \\
\hline 81 & east \\
\hline 82 & southwest \\
\hline 83 & south \\
\hline 84 & west \\
\hline 85 & northwest \\
\hline 86 & southwest \\
\hline 87 & east \\
\hline 88 & west \\
\hline 89 & east \\
\hline 90 & southeast \\
\hline 91 & northwest \\
\hline 92 & southwest \\
\hline 93 & south \\
\hline 94 & northwest \\
\hline 95 & northeast \\
\hline 96 & southwest \\
\hline 97 & west \\
\hline 98 & northwest \\
\hline 99 & northwest \\
\hline 100 & southeast \\
\hline 101 & northwest \\
\hline 102 & east \\
\hline 103 & south \\
\hline 104 & south \\
\hline 105 & west \\
\hline 106 & west \\
\hline 107 & north \\
\hline 108 & southwest \\
\hline 109 & east \\
\hline 110 & southwest \\
\hline 111 & northwest \\
\hline 112 & southwest \\
\hline 113 & northeast \\
\hline 114 & west \\
\hline 115 & south \\
\hline 116 & west \\
\hline 117 & west \\
\hline 118 & southeast \\
\hline 119 & northeast \\
\hline 120 & east \\
\hline 121 & northeast \\
\hline 122 & northeast \\
\hline 123 & south \\
\hline 124 & north \\
\hline 125 & west \\
\hline 126 & west \\
\hline 127 & northeast \\
\hline 128 & southeast \\
\hline 129 & southwest \\
\hline 130 & northeast \\
\hline
\end{tabular}

\begin{tabular}{|c|c|}
\hline 131 & north \\
\hline 132 & east \\
\hline 133 & southwest \\
\hline 134 & west \\
\hline 135 & northwest \\
\hline 136 & west \\
\hline 137 & northeast \\
\hline 138 & southwest \\
\hline 139 & west \\
\hline 140 & north \\
\hline 141 & south \\
\hline 142 & north \\
\hline 143 & northwest \\
\hline 144 & north \\
\hline 145 & north \\
\hline 146 & north \\
\hline 147 & northeast \\
\hline 148 & south \\
\hline 149 & southwest \\
\hline 150 & south \\
\hline 151 & southwest \\
\hline 152 & southwest \\
\hline 153 & northwest \\
\hline 154 & northwest \\
\hline 155 & northeast \\
\hline 156 & southwest \\
\hline 157 & northwest \\
\hline 158 & southwest \\
\hline 159 & south \\
\hline 160 & west \\
\hline 161 & east \\
\hline 162 & southwest \\
\hline 163 & northwest \\
\hline 164 & northwest \\
\hline 165 & southwest \\
\hline 166 & south \\
\hline 167 & southwest \\
\hline 168 & northwest \\
\hline 169 & south \\
\hline 170 & north \\
\hline 171 & northwest \\
\hline 172 & west \\
\hline 173 & south \\
\hline 174 & south \\
\hline 175 & south \\
\hline 176 & east \\
\hline 177 & west \\
\hline 178 & northeast \\
\hline 179 & south \\
\hline 180 & north \\
\hline 181 & south \\
\hline 182 & east \\
\hline 183 & east \\
\hline 184 & west \\
\hline 185 & south \\
\hline 186 & northwest \\
\hline 187 & west \\
\hline 188 & west \\
\hline 189 & southeast \\
\hline 190 & west \\
\hline 191 & north \\
\hline 192 & southwest \\
\hline 193 & northeast \\
\hline 194 & south \\
\hline 195 & southwest \\
\hline 196 & southwest \\
\hline 197 & southwest \\
\hline 198 & northwest \\
\hline 19 & \\
\hline
\end{tabular}

\begin{tabular}{|c|c|}
\hline 200 & northeast \\
\hline 201 & southwest \\
\hline 202 & west \\
\hline 203 & west \\
\hline 204 & southeast \\
\hline 205 & southeast \\
\hline 206 & southwest \\
\hline 207 & southwest \\
\hline 208 & west \\
\hline 209 & west \\
\hline 210 & southwest \\
\hline 211 & south \\
\hline 212 & southeast \\
\hline 213 & southwest \\
\hline 214 & west \\
\hline 215 & northwest \\
\hline 216 & northwest \\
\hline 217 & northwest \\
\hline 218 & southeast \\
\hline 219 & north \\
\hline 220 & southeast \\
\hline 221 & northwest \\
\hline 222 & northeast \\
\hline 223 & northwest \\
\hline 224 & south \\
\hline 225 & west \\
\hline 226 & east \\
\hline 227 & south \\
\hline 228 & southwest \\
\hline 229 & northwest \\
\hline 230 & south \\
\hline 231 & northeast \\
\hline 232 & southeast \\
\hline 233 & northwest \\
\hline 234 & southwest \\
\hline 235 & west \\
\hline 236 & north \\
\hline 237 & northeast \\
\hline 238 & southeast \\
\hline 239 & west \\
\hline 240 & northwest \\
\hline 241 & northeast \\
\hline 242 & northwest \\
\hline 243 & southwest \\
\hline 244 & southwest \\
\hline 245 & east \\
\hline 246 & east \\
\hline 247 & northwest \\
\hline 248 & northeast \\
\hline 249 & southwest \\
\hline 250 & south \\
\hline 251 & northeast \\
\hline 252 & west \\
\hline 253 & west \\
\hline 254 & west \\
\hline 255 & south \\
\hline 256 & west \\
\hline 257 & southeast \\
\hline 258 & northeast \\
\hline 259 & northwest \\
\hline 260 & northwest \\
\hline 261 & southwest \\
\hline 262 & northeast \\
\hline 263 & southwest \\
\hline 264 & south \\
\hline 265 & west \\
\hline 266 & west \\
\hline 267 & east \\
\hline 268 & east \\
\hline
\end{tabular}

\begin{tabular}{|c|c|}
\hline 269 & southeast \\
\hline 270 & southeast \\
\hline 271 & north \\
\hline 272 & west \\
\hline 273 & west \\
\hline 274 & southwest \\
\hline 275 & east \\
\hline 276 & south \\
\hline 277 & southwest \\
\hline 278 & northeast \\
\hline 279 & east \\
\hline 280 & east \\
\hline 281 & southeast \\
\hline 282 & south \\
\hline 283 & south \\
\hline 284 & west \\
\hline 285 & west \\
\hline 286 & northeast \\
\hline 287 & southeast \\
\hline 288 & southeast \\
\hline 289 & southwest \\
\hline 290 & east \\
\hline 291 & southeast \\
\hline 292 & east \\
\hline 293 & south \\
\hline 294 & southeast \\
\hline 295 & west \\
\hline 296 & southwest \\
\hline 297 & south \\
\hline 298 & northeast \\
\hline 299 & northwest \\
\hline 300 & south \\
\hline 301 & southeast \\
\hline 302 & southwest \\
\hline 303 & southwest \\
\hline 304 & north \\
\hline 305 & southeast \\
\hline 306 & west \\
\hline 307 & northeast \\
\hline 308 & southwest \\
\hline 309 & south \\
\hline 310 & south \\
\hline 311 & south \\
\hline 312 & west \\
\hline 313 & south \\
\hline 314 & northwest \\
\hline 315 & northeast \\
\hline 316 & east \\
\hline 317 & south \\
\hline 318 & north \\
\hline 319 & southwest \\
\hline 320 & southeast \\
\hline 321 & southwest \\
\hline 322 & northwest \\
\hline 323 & southeast \\
\hline 324 & west \\
\hline 325 & northwest \\
\hline 326 & east \\
\hline 327 & southwest \\
\hline 328 & south \\
\hline 329 & northwest \\
\hline 330 & west \\
\hline 331 & southwest \\
\hline 332 & south \\
\hline 333 & northeast \\
\hline 334 & southeast \\
\hline 335 & southeast \\
\hline 336 & south \\
\hline 337 & southwest \\
\hline
\end{tabular}

\begin{tabular}{|c|c|}
\hline 338 & east \\
\hline 339 & southwest \\
\hline 340 & southwest \\
\hline 341 & southwest \\
\hline 342 & south \\
\hline 343 & southwest \\
\hline 344 & south \\
\hline 345 & southwest \\
\hline 346 & southwest \\
\hline 347 & northeast \\
\hline 348 & southeast \\
\hline 349 & southwest \\
\hline 350 & southwest \\
\hline 351 & west \\
\hline 352 & southwest \\
\hline 353 & southwest \\
\hline 354 & southwest \\
\hline 355 & southwest \\
\hline 356 & southeast \\
\hline 357 & southwest \\
\hline 358 & southwest \\
\hline 359 & south \\
\hline 360 & southwest \\
\hline 361 & southwest \\
\hline 362 & south \\
\hline 363 & east \\
\hline 364 & north \\
\hline
\end{tabular}




\section{S7. Frequency distribution table wind speeds}

Tab. SI4. Frequency distribution table for 20 wind speed classes. This table is directly derived from the wind speed frequency table named "Frequentietabellen Windsnelheid in m/s, Distributief in procenten, De Bilf' [6]. The table below indicates for each month the frequency with which the hourly averaged wind speeds (recorded by the Royal Netherlands Meteorological Institute (KNMI) in the period 1981 - 2000 at weather station De Bilt) fell within 20 wind speed classes. The De Bilt weather station is located at 52.1015441 latitude and 5.1779992 longitude, the Netherlands. We used the frequencies in the table below to pick a wind speed class for each time step of the model application. For this we used the NumPy function numpy.random.choice $([\mathrm{A}], \mathrm{p}=[\mathrm{B}])$, in which $\mathrm{A}$ is an array filled with the numbers 1 to 20 , representing the 20 wind speed classes, and B is an array filled with the 20 frequency values for a specific month depending on in which month the time step falls (assume not a leap year). After a wind speed class has been chosen, the model randomly picks a wind speed value between the limits (second column in the table below) of that wind speed class.

\begin{tabular}{|c|c|c|c|c|c|c|c|c|c|c|c|c|c|}
\hline $\begin{array}{l}\frac{\pi}{0} \\
\frac{\pi}{U}\end{array}$ & 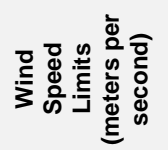 & 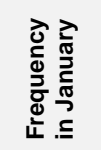 & 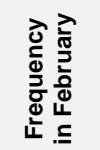 & 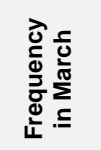 & 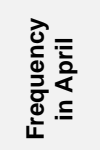 & 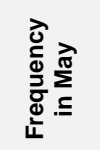 & 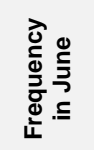 & 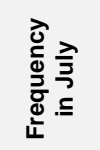 & 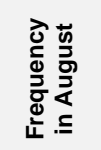 & 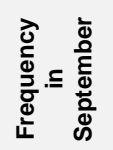 & 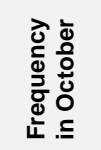 & 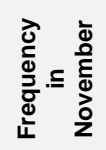 & 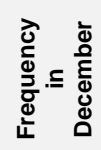 \\
\hline 1 & $0.0-0.4$ & 0.0035 & 0.0034 & 0.0056 & 0.0027 & 0.0042 & 0.0044 & 0.0058 & 0.0120 & 0.0115 & 0.0065 & 0.0039 & 0.0040 \\
\hline 2 & $0.5-1.4$ & 0.0938 & 0.0858 & 0.0995 & 0.1181 & 0.1234 & 0.1231 & 0.1419 & 0.1903 & 0.1926 & 0.1428 & 0.1185 & 0.1040 \\
\hline 3 & $1.5-2.4$ & 0.1517 & 0.1578 & 0.1610 & 0.1900 & 0.2076 & 0.2238 & 0.2450 & 0.2586 & 0.2435 & 0.2118 & 0.2070 & 0.1774 \\
\hline 4 & $2.5-3.4$ & 0.1680 & 0.1993 & 0.1960 & 0.2136 & 0.2357 & 0.2531 & 0.2466 & 0.2302 & 0.2251 & 0.2122 & 0.1988 & 0.1873 \\
\hline 5 & $3.5-4.4$ & 0.1639 & 0.1700 & 0.1739 & 0.1878 & 0.1957 & 0.2088 & 0.1915 & 0.1681 & 0.1544 & 0.1749 & 0.1688 & 0.1600 \\
\hline 6 & $4.5-5.4$ & 0.1401 & 0.1434 & 0.1284 & 0.1352 & 0.1281 & 0.1194 & 0.1117 & 0.0840 & 0.0959 & 0.1139 & 0.1318 & 0.1350 \\
\hline 7 & $5.5-6.4$ & 0.1049 & 0.0916 & 0.0925 & 0.0815 & 0.0608 & 0.0471 & 0.0413 & 0.0370 & 0.0483 & 0.0644 & 0.0874 & 0.0976 \\
\hline 8 & $6.5-7.4$ & 0.0761 & 0.0645 & 0.0690 & 0.0442 & 0.0297 & 0.0147 & 0.0118 & 0.0156 & 0.0200 & 0.0388 & 0.0494 & 0.0630 \\
\hline 9 & $7.5-8.4$ & 0.0470 & 0.0428 & 0.0355 & 0.0187 & 0.0110 & 0.0042 & 0.0034 & 0.0033 & 0.0066 & 0.0214 & 0.0235 & 0.0357 \\
\hline 10 & $8.5-9.4$ & 0.0272 & 0.0255 & 0.0190 & 0.0056 & 0.0026 & 0.0011 & 0.0009 & 0.0009 & 0.0016 & 0.0068 & 0.0061 & 0.0178 \\
\hline 11 & $9.5-10.4$ & 0.0142 & 0.0097 & 0.0117 & 0.0021 & 0.0007 & 0.0003 & 0.0001 & 0.0001 & 0.0004 & 0.0042 & 0.0024 & 0.0101 \\
\hline 12 & $10.5-11.4$ & 0.0047 & 0.0032 & 0.0050 & 0.0001 & 0.0001 & 0.0000 & 0.0000 & 0.0000 & 0.0000 & 0.0013 & 0.0010 & 0.0048 \\
\hline 13 & $11.5-12.4$ & 0.0032 & 0.0024 & 0.0021 & 0.0002 & 0.0002 & 0.0000 & 0.0000 & 0.0000 & 0.0000 & 0.0007 & 0.0006 & 0.0024 \\
\hline 14 & $12.5-13.4$ & 0.0009 & 0.0005 & 0.0007 & 0.0000 & 0.0001 & 0.0000 & 0.0000 & 0.0000 & 0.0000 & 0.0002 & 0.0001 & 0.0007 \\
\hline 15 & $13.5-14.4$ & 0.0005 & 0.0003 & 0.0002 & 0.0002 & 0.0000 & 0.0000 & 0.0000 & 0.0000 & 0.0000 & 0.0000 & 0.0001 & 0.0001 \\
\hline 16 & $14.5-15.4$ & 0.0001 & 0.0000 & 0.0000 & 0.0000 & 0.0000 & 0.0000 & 0.0000 & 0.0000 & 0.0000 & 0.0000 & 0.0001 & 0.0001 \\
\hline 17 & $15.5-16.4$ & 0.0001 & 0.0000 & 0.0000 & 0.0001 & 0.0000 & 0.0000 & 0.0000 & 0.0000 & 0.0000 & 0.0000 & 0.0001 & 0.0000 \\
\hline 18 & $16.5-17.4$ & 0.0000 & 0.0000 & 0.0000 & 0.0000 & 0.0000 & 0.0000 & 0.0000 & 0.0000 & 0.0000 & 0.0000 & 0.0002 & 0.0000 \\
\hline 19 & $17.5-18.4$ & 0.0002 & 0.0000 & 0.0000 & 0.0000 & 0.0000 & 0.0000 & 0.0000 & 0.0000 & 0.0000 & 0.0000 & 0.0000 & 0.0000 \\
\hline 20 & $18.5-19.4$ & 0.0000 & 0.0000 & 0.0000 & 0.0000 & 0.0000 & 0.0000 & 0.0000 & 0.0000 & 0.0000 & 0.0000 & 0.0000 & 0.0000 \\
\hline
\end{tabular}




\section{S8. Frequency distribution table wind directions}

Tab. SI5. Frequency distribution table for 37 wind direction classes. This table is directly derived from the wind direction frequency table named "Frequentietabellen Windrichting in graden, Distributief in procenten, De Bilt' [7]). The table indicates for each month the frequency with which the hourly averaged wind directions (recorded by the Royal Netherlands Meteorological Institute (KNMI) in the period 1981 - 2000 at weather station De Bilt) fell within 37 wind direction classes. The De Bilt weather station is located at 52.1015441 latitude and 5.1779992 longitude, the Netherlands. We used the frequencies in the table below to pick a wind direction class for each time step of the model application. For this we used the NumPy function numpy.random.choice([A], $\mathrm{p}=[\mathrm{B}])$, in which $\mathrm{A}$ is an array filled with the numbers 1 to 37 , representing the 37 wind direction classes, and B is an array filled with the 37 frequency values for a specific month depending on in which month the time step falls (assume not a leap year). After a wind speed class has been chosen, the model randomly picks a wind direction value between the limits (second column in the table below) of that wind direction class. Finally, the wind directions conversion table (Tab. SI2) is used to fit the selected wind direction into one of the eight wind directions used in the model and determine the direction in which plastics that are carried by the wind are transported. Tab. SI3 shows the wind directions that were generated in this way for the model application presented in this study.

\begin{tabular}{|c|c|c|c|c|c|c|c|c|c|c|c|c|c|}
\hline $\begin{array}{l}\frac{5}{8} \\
\frac{\pi}{0}\end{array}$ & 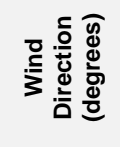 & 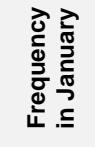 & 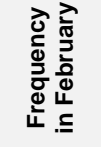 & 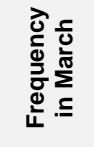 & 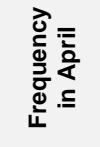 & 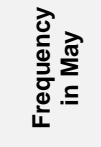 & 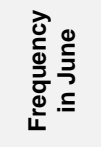 & 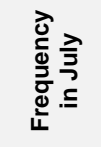 & 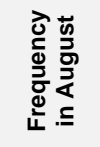 & 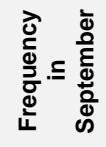 & 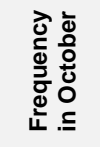 & 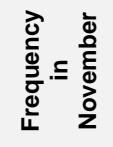 & 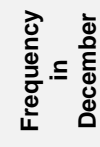 \\
\hline 1 & * & 0.0319 & 0.0350 & 0.0396 & 0.0442 & 0.0591 & 0.0544 & 0.0637 & 0.0882 & 0.0784 & 0.0568 & 0.0459 & 0.0374 \\
\hline 2 & $5-14$ & 0.0074 & 0.0124 & 0.0112 & 0.0284 & 0.0288 & 0.0233 & 0.0152 & 0.0170 & 0.0110 & 0.0063 & 0.0071 & 0.0082 \\
\hline 3 & $15-24$ & 0.0088 & 0.0211 & 0.0175 & 0.0309 & 0.0335 & 0.0284 & 0.0216 & 0.0243 & 0.0152 & 0.0106 & 0.0078 & 0.0104 \\
\hline 4 & $25-34$ & 0.0149 & 0.0285 & 0.0226 & 0.0347 & 0.0411 & 0.0342 & 0.0343 & 0.0280 & 0.0219 & 0.0170 & 0.0153 & 0.0144 \\
\hline 5 & $35-44$ & 0.0231 & 0.0290 & 0.0212 & 0.0438 & 0.0404 & 0.0336 & 0.0338 & 0.0300 & 0.0275 & 0.0167 & 0.0153 & 0.0219 \\
\hline 6 & $45-54$ & 0.0223 & 0.0229 & 0.0148 & 0.0370 & 0.0325 & 0.0255 & 0.0202 & 0.0188 & 0.0205 & 0.0157 & 0.0172 & 0.0231 \\
\hline 7 & $55-64$ & 0.0161 & 0.0218 & 0.0138 & 0.0234 & 0.0234 & 0.0179 & 0.0148 & 0.0141 & 0.0167 & 0.0145 & 0.0161 & 0.0188 \\
\hline 8 & $65-74$ & 0.0219 & 0.0320 & 0.0169 & 0.0221 & 0.0255 & 0.0138 & 0.0149 & 0.0179 & 0.0156 & 0.0208 & 0.0158 & 0.0229 \\
\hline 9 & $75-84$ & 0.0258 & 0.0360 & 0.0190 & 0.0207 & 0.0300 & 0.0146 & 0.0165 & 0.0157 & 0.0162 & 0.0247 & 0.0196 & 0.0277 \\
\hline 10 & $85-94$ & 0.0171 & 0.0265 & 0.0224 & 0.0208 & 0.0279 & 0.0152 & 0.0150 & 0.0152 & 0.0167 & 0.0216 & 0.0201 & 0.0190 \\
\hline 11 & $95-104$ & 0.0120 & 0.0187 & 0.0170 & 0.0163 & 0.0233 & 0.0126 & 0.0147 & 0.0144 & 0.0183 & 0.0222 & 0.0190 & 0.0153 \\
\hline 12 & $105-114$ & 0.0130 & 0.0153 & 0.0132 & 0.0163 & 0.0163 & 0.0129 & 0.0091 & 0.0135 & 0.0158 & 0.0188 & 0.0203 & 0.0150 \\
\hline 13 & $115-124$ & 0.0116 & 0.0122 & 0.0140 & 0.0148 & 0.0163 & 0.0111 & 0.0106 & 0.0123 & 0.0193 & 0.0182 & 0.0233 & 0.0142 \\
\hline 14 & $125-134$ & 0.0202 & 0.0196 & 0.0209 & 0.0206 & 0.0189 & 0.0107 & 0.0122 & 0.0124 & 0.0249 & 0.0245 & 0.0353 & 0.0207 \\
\hline 15 & $135-144$ & 0.0265 & 0.0194 & 0.0242 & 0.0249 & 0.0204 & 0.0156 & 0.0155 & 0.0185 & 0.0267 & 0.0344 & 0.0372 & 0.0268 \\
\hline 16 & $145-154$ & 0.0329 & 0.0198 & 0.0259 & 0.0256 & 0.0235 & 0.0174 & 0.0173 & 0.0226 & 0.0319 & 0.0401 & 0.0422 & 0.0298 \\
\hline 17 & $155-164$ & 0.0358 & 0.0299 & 0.0314 & 0.0303 & 0.0246 & 0.0196 & 0.0197 & 0.0263 & 0.0363 & 0.0483 & 0.0421 & 0.0351 \\
\hline 18 & $165-174$ & 0.0377 & 0.0350 & 0.0287 & 0.0289 & 0.0210 & 0.0164 & 0.0169 & 0.0231 & 0.0293 & 0.0438 & 0.0471 & 0.0357 \\
\hline 19 & $175-184$ & 0.0353 & 0.0287 & 0.0265 & 0.0242 & 0.0201 & 0.0157 & 0.0157 & 0.0210 & 0.0299 & 0.0359 & 0.0408 & 0.0358 \\
\hline 20 & $185-194$ & 0.0485 & 0.0372 & 0.0289 & 0.0275 & 0.0219 & 0.0233 & 0.0237 & 0.0299 & 0.0390 & 0.0475 & 0.0532 & 0.0489 \\
\hline 21 & $195-204$ & 0.0530 & 0.0476 & 0.0415 & 0.0311 & 0.0247 & 0.0304 & 0.0292 & 0.0351 & 0.0444 & 0.0558 & 0.0568 & 0.0543 \\
\hline 22 & $205-214$ & 0.0530 & 0.0469 & 0.0438 & 0.0284 & 0.0261 & 0.0337 & 0.0372 & 0.0384 & 0.0467 & 0.0585 & 0.0503 & 0.0563 \\
\hline 23 & $215-224$ & 0.0638 & 0.0546 & 0.0476 & 0.0313 & 0.0317 & 0.0485 & 0.0443 & 0.0472 & 0.0514 & 0.0687 & 0.0576 & 0.0633 \\
\hline 24 & $225-234$ & 0.0729 & 0.0590 & 0.0576 & 0.0358 & 0.0344 & 0.0525 & 0.0505 & 0.0489 & 0.0522 & 0.0572 & 0.0552 & 0.0631 \\
\hline
\end{tabular}




\begin{tabular}{|c|c|c|c|c|c|c|c|c|c|c|c|c|c|}
\hline 25 & $235-244$ & 0.0594 & 0.0531 & 0.0644 & 0.0367 & 0.0368 & 0.0433 & 0.0458 & 0.0443 & 0.0422 & 0.0394 & 0.0397 & 0.0569 \\
\hline 26 & $245-254$ & 0.0388 & 0.0348 & 0.0501 & 0.0269 & 0.0253 & 0.0349 & 0.0366 & 0.0355 & 0.0291 & 0.0279 & 0.0291 & 0.0358 \\
\hline 27 & $255-264$ & 0.0338 & 0.0313 & 0.0407 & 0.0272 & 0.0210 & 0.0367 & 0.0384 & 0.0356 & 0.0301 & 0.0271 & 0.0281 & 0.0366 \\
\hline 28 & $265-274$ & 0.0303 & 0.0281 & 0.0364 & 0.0235 & 0.0252 & 0.0403 & 0.0439 & 0.0349 & 0.0313 & 0.0250 & 0.0283 & 0.0327 \\
\hline 29 & $275-284$ & 0.0249 & 0.0279 & 0.0328 & 0.0254 & 0.0223 & 0.0384 & 0.0376 & 0.0326 & 0.0258 & 0.0179 & 0.0233 & 0.0254 \\
\hline 30 & $285-294$ & 0.0198 & 0.0223 & 0.0272 & 0.0244 & 0.0190 & 0.0326 & 0.0313 & 0.0259 & 0.0197 & 0.0127 & 0.0142 & 0.0172 \\
\hline 31 & $295-304$ & 0.0173 & 0.0188 & 0.0231 & 0.0262 & 0.0200 & 0.0328 & 0.0349 & 0.0235 & 0.0173 & 0.0112 & 0.0138 & 0.0150 \\
\hline 32 & $305-314$ & 0.0159 & 0.0172 & 0.0276 & 0.0270 & 0.0237 & 0.0319 & 0.0358 & 0.0292 & 0.0185 & 0.0108 & 0.0165 & 0.0141 \\
\hline 33 & $315-324$ & 0.0157 & 0.0152 & 0.0220 & 0.0270 & 0.0296 & 0.0343 & 0.0392 & 0.0296 & 0.0228 & 0.0128 & 0.0121 & 0.0122 \\
\hline 34 & $325-334$ & 0.0117 & 0.0125 & 0.0165 & 0.0251 & 0.0351 & 0.0309 & 0.0343 & 0.0267 & 0.0195 & 0.0114 & 0.0106 & 0.0134 \\
\hline 35 & $335-344$ & 0.0099 & 0.0105 & 0.0157 & 0.0223 & 0.0288 & 0.0228 & 0.0237 & 0.0195 & 0.0156 & 0.0075 & 0.0096 & 0.0080 \\
\hline 36 & $345-354$ & 0.0083 & 0.0088 & 0.0120 & 0.0238 & 0.0254 & 0.0194 & 0.0175 & 0.0159 & 0.0113 & 0.0087 & 0.0071 & 0.0076 \\
\hline 37 & $355-4$ & 0.0087 & 0.0104 & 0.0114 & 0.0224 & 0.0226 & 0.0206 & 0.0144 & 0.0140 & 0.0113 & 0.0088 & 0.0069 & 0.0071 \\
\hline
\end{tabular}

820 * No wind or wind directions were too variable

\section{Graph rainfall for the model application}

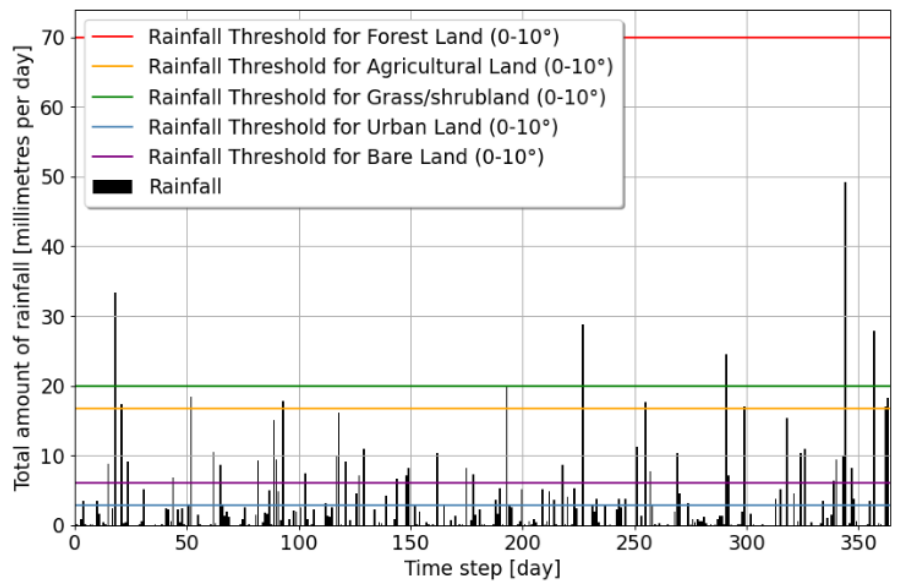

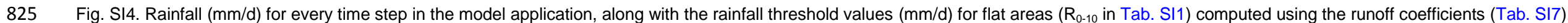


Tab. SI6. Frequency distribution for 23 rainfall classes. This table has been calculated from the rainfall table named " $R H$, Etmaalsom van de neerslag (in $0.1 \mathrm{~mm})(-1$ voor $<0.05 \mathrm{~mm}$ )" [5]. The rainfall table contains for each day (from 1 January 1981 up and until 31 December 2000) the total amount of rainfall (in millimetres) recorded by the Royal Netherlands Meteorological Institute (KNMI) at weather station De Bilt. The De Bilt station is located at 52.1015441 latitude and 5.1779992 longitude, the Netherlands. Each day was assigned to one of the 23 rainfall classes based on the total amount of rainfall that fell during that day. Subsequently, the frequencies for each rainfall class were computed. We did not take monthly variations into account, therefore the frequencies in the table hold for all months. The model uses the created frequency distribution table to pick a rainfall class for each time step of the model application using the NumPy function numpy.random.choice $([A], p=[B])$, in which $A$ is an array filled with the numbers 1 to 23 , representing the 23 rainfall classes, and B is an array filled with the 23 frequency values. Finally, the Trash-Tracker randomly picks a total rainfall value that fits within the limits (second column in the table below) of the selected rainfall class. Fig. SI4 shows the rainfall values that were generated in this way for the model application presented in this study.

\begin{tabular}{c|c|c} 
Rainfall Class & Rainfall Limits (millimetres per day) & Frequency (all months) \\
\hline $\mathbf{1}$ & 0 (no rainfall) & 0.3247 \\
$\mathbf{2}$ & $0.001-0.100$ & 0.1771 \\
$\mathbf{3}$ & $0.101-1.000$ & 0.1396 \\
$\mathbf{4}$ & $1.001-2.000$ & 0.0758 \\
$\mathbf{5}$ & $2.001-3.000$ & 0.0531 \\
$\mathbf{6}$ & $3.001-4.000$ & 0.0393 \\
$\mathbf{7}$ & $4.001-5.000$ & 0.0342 \\
$\mathbf{8}$ & $5.001-6.000$ & 0.0256 \\
$\mathbf{9}$ & $6.001-7.000$ & 0.0203 \\
$\mathbf{1 0}$ & $7.001-8.000$ & 0.0179 \\
$\mathbf{1 1}$ & $8.001-9.000$ & 0.0155 \\
$\mathbf{1 2}$ & $9.001-10.000$ & 0.0134 \\
$\mathbf{1 3}$ & $10.001-11.000$ & 0.0100 \\
$\mathbf{1 4}$ & $11.001-12.000$ & 0.0086 \\
$\mathbf{1 5}$ & $12.001-13.000$ & 0.0060 \\
$\mathbf{1 6}$ & $13.001-14.000$ & 0.0055 \\
$\mathbf{1 7}$ & $14.001-15.000$ & 0.0059 \\
$\mathbf{1 8}$ & $15.001-16.000$ & 0.0045 \\
$\mathbf{1 9}$ & $16.001-17.000$ & 0.0029 \\
$\mathbf{2 0}$ & $17.001-18.000$ & 0.0033 \\
$\mathbf{2 1}$ & $18.001-19.000$ & 0.0038 \\
$\mathbf{2 2}$ & $19.001-20.000$ & 0.0018 \\
$\mathbf{2 3}$ & $>20.000$ & 0.0111 \\
& &
\end{tabular}

\section{S11. Table runoff coefficients}

Tab. SI7. Runoff Coefficients (= runoff / rainfall) used by the Trash-Tracker to convert the amount of rainfall in millimetres per day to the amount of surface runoff in millimetres per day. Values based on typical runoff coefficients reported by Goel [1] and Karamage et al. [2].

\begin{tabular}{l|c} 
Type of land use & Runoff Coefficient \\
\hline River & 1.00 \\
Urban land & 0.70 \\
Bare land & 0.50 \\
Agricultural land & 0.30 \\
Grass/Shrubland & 0.20 \\
Forest & 0.10
\end{tabular}




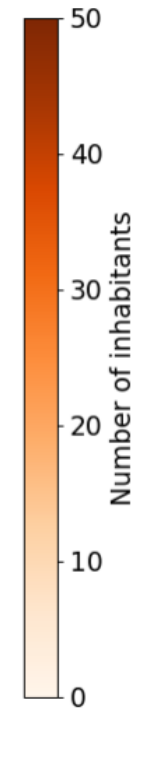

Fig. SI5. Population density map of the hypothetical river basin used for the model application. Colours indicate the number of inhabitants per grid cell.

\section{S13. Threshold maps generated by model application}

a.

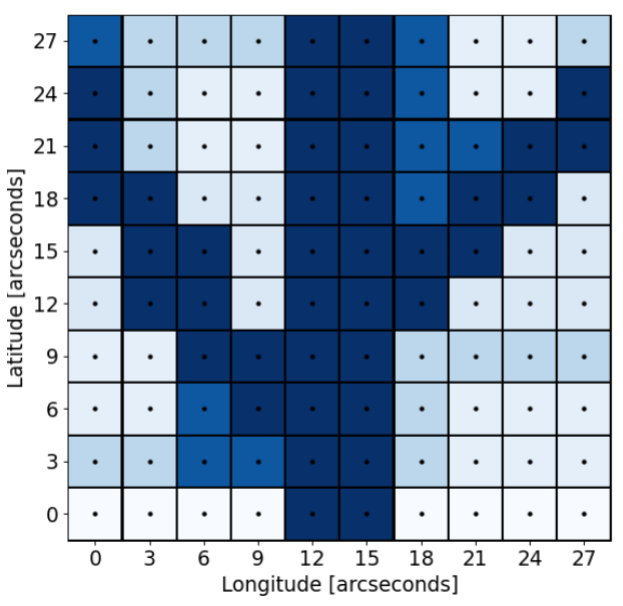

b.

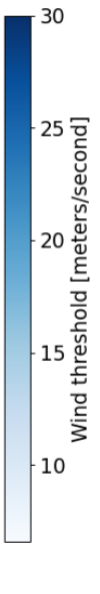

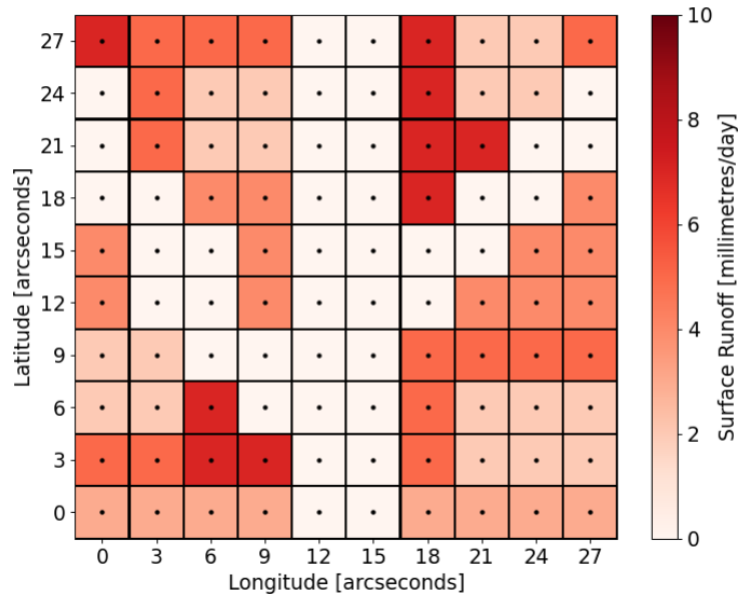

Fig. SI6. Wind speed (a) and surface runoff (b) threshold maps that show for each grid cell in the model domain the critical wind speed (in $\mathrm{m} / \mathrm{s}$ ) and surface runoff flux ( $\mathrm{mm} / \mathrm{d}$ ) that is required to mobilise and transport plastics to a neighbouring grid cell. Wind speed thresholds for the model application were calculated using Option 1 (see section 2.5), i.e. they depend only on the type of land use (the 'Flat terrain' values in Tab. SI1). 


\section{References for Supplementary Information}

1. Goel MK. Runoff coefficient. In: Encyclopedia of Snow, Ice and Glaciers. Dordrecht: Springer; 2011. p. 952-3. http://dx.doi.org/10.1007/978-90-481-2642-2 456.

2. Karamage F, Zhang C, Fang X, Liu T, Ndayisaba F, Nahayo L, et al. Modeling rainfall-runoff response to land use and land cover change in Rwanda (1990-2016). Water (Basel). 2017;9(2):147 http://dx.doi.org/10.3390/w9020147.

3. Meijer L, van Emmerik T, Lebreton L, Schmidt C, van der Ent R. Over 1000 rivers accountable for $80 \%$ of global riverine plastic emissions into the ocean. EarthArXiv. 2019 http://dx.doi.org/10.31223/osf.io/zigty.

4. Met Office. National Meteorological Library and Archive Fact sheet 6 - The Beaufort Scale. 2010. https://web.archive.org/web/20121002134429/http://www.metoffice.gov.uk/media/pdf/4/4/Fact Sheet No. 6 - Beaufort Scale.pdf.

5. Royal Netherlands Meteorological Institute (KNMI). Daggegevens van het weer in Nederland, $\mathrm{RH}$, Etmaalsom van de neerslag (in $0.1 \mathrm{~mm})(-1$ voor $<0.05 \mathrm{~mm})$.

6. Royal Netherlands Meteorological Institute (KNMI). Frequentietabellen Windsnelheid in $\mathrm{m} / \mathrm{s}$, Distributief in procenten, De Bilt. http://projects.knmi.nl/klimatologie/frequentietabellen/maand.cgi. Accessed 29 May 2020.

7. Royal Netherlands Meteorological Institute (KNMI). Frequentietabellen Windrichting in graden, Distributief in procenten, De Bilt. http://projects.knmi.nl/klimatologie/frequentietabellen/maand.cgi. Accessed 29 May 2020. 